\title{
The properties and genesis environments of South Atlantic cyclones
}

Article

Accepted Version

Gramcianinov, C. B., Hodges, K. I. and Camargo, R. (2019) The properties and genesis environments of South Atlantic cyclones. Climate Dynamics, 53 (7-8). pp. 4115-4140. ISSN 1432-0894 doi: https://doi.org/10.1007/s00382-019-04778-1 Available at https://centaur.reading.ac.uk/80949/

It is advisable to refer to the publisher's version if you intend to cite from the work. See Guidance on citing.

To link to this article DOI: http://dx.doi.org/10.1007/s00382-019-04778-1

Publisher: Springer

All outputs in CentAUR are protected by Intellectual Property Rights law, including copyright law. Copyright and IPR is retained by the creators or other copyright holders. Terms and conditions for use of this material are defined in the End User Agreement.

\section{www.reading.ac.uk/centaur}

\section{CentAUR}

Central Archive at the University of Reading

Reading's research outputs online 


\title{
The Properties and Genesis Environments of South Atlantic Cyclones
}

\author{
C. B. Gramcianinov - K. I. Hodges • R. \\ Camargo
}

6 Received: date / Accepted: date

7 Abstract A new climatology of South Atlantic cyclones is produced to provide new insights into the conditions leading to genesis in different regions of the domain. Cyclones are identified and tracked based on the relative vorticity at $850 \mathrm{hPa}$ computed from the NCEP-CFSR winds. The characteristics of the cyclones are obtained by diagnostic variables sampled within a radial distance from the cyclone centers to produce the spatial distribution of cyclone properties at the time of genesis. Also, cyclone centered composites are used to analyze the cyclone structure and evolution during their genesis. There are four main cyclogenesis regions in the South Atlantic Ocean: the Southern Brazilian coast (SE-BR, $30^{\circ} \mathrm{S}$ ), over the continent near the La Plata river discharge region (LA PLATA, $35^{\circ} \mathrm{S}$ ), the southeastern coast of Argentina (ARG, $40^{\circ} \mathrm{S}-55^{\circ} \mathrm{S}$ ) and the Southeastern Atlantic (SE-SAO, centered at $45^{\circ} \mathrm{S}$ and $10^{\circ} \mathrm{W}$ ). We found that cyclogenesis northward of $35^{\circ} \mathrm{S}$ occurs mainly due to low-level forcing associated with moisture transport in the summer, and is associated with upper-level forcing in the winter due to a strong baroclinic environment. Southward of $35^{\circ} \mathrm{S}$, cyclones develop in a high baroclinic environment throughout the year with only a small influence from moist processes. The cyclone composites reveal that SE-BR and SE-SAO cyclones are associated with secondary development, the LA PLATA cyclones development is influenced by an orographic low in their early stages, and ARG cyclones are

C. B. Gramcianinov

Departamento de Ciências Atmosféricas, Instituto de Astronomia, Geofísica e Ciências Atmosféricas, Universidade de São Paulo, Rua do Matão, 1226, Cidade Universitária, São Paulo/SP - Brazil.

E-mail: carolina.gramcianinov@alumni.usp.br

K. I. Hodges

Department of Meteorology, University of Reading

R. Camargo

Departamento de Ciências Atmosféricas, Instituto de Astronomia, Geofísica e Ciências Atmosféricas, Universidade de São Paulo 
influenced by thermal advection as an essential mechanism in the reduction of static stability.

Keywords Cyclogenesis · Extratropical Cyclones · South America · Storm track

\section{Introduction}

Cyclones play a crucial role in the weather and climate of the South American continent, where the major part of the population lives in coastal cities, surrounded by regions of cyclogenesis (Gan and Rao, 1991; Sinclair, 1995; Hoskins and Hodges, 2005; Reboita et al, 2010a). Surface cyclones are responsible for the major precipitation in the Southeast of South America and the maintenance of the South Atlantic Convergence Zone (SACZ) during the South America Monsoon (Reboita et al, 2010b). Besides this, cyclones are related to several natural hazards along the coast through storm surges and flooding (e.g., Seluchi and Saulo, 1998; Parise et al, 2009), and wave generation (e.g., Innocentini and Neto, 1996; da Rocha et al, 2004) causing damage to economic activities such as oil exploration, harbors and navigation. Therefore, understanding the dynamical characteristics of these systems and their development is essential for mitigation policies and improvements in prediction methods.

During previous decades, several studies have led to a better understanding of the distribution of cyclones and their development in the Southern Hemisphere through synoptic analysis (Taljaard, 1967) and automated tracking methods, using satellite data (Streten and Troup, 1973; Satyamurty et al, 1990), operational analyses (Jones and Simmonds, 1993; Sinclair, 1994) and reanalyses (Simmonds and Keay, 2000; Hoskins and Hodges, 2005). Extratropical cyclones in the Southern Hemisphere primarily occur within $55^{\circ} \mathrm{S}$ to $35^{\circ} \mathrm{S}$ (maximum at $45^{\circ} \mathrm{S}$ ) and near Antarctica (e.g. Hoskins and Hodges, 2005). During the austral summer (DJF) the main storm track shifts poleward (Taljaard, 1967). The preferential orientation is in a south-southeast direction with a spiral pattern towards Antarctica in the winter (e.g., Hoskins and Hodges, 2005). In previous studies, the eastern coast of South America has always been highlighted as an important genesis region for the Southern Hemisphere.

One of the first studies with a regional focus on the South Atlantic was performed by Gan and Rao (1991) who used sea level pressure synoptic charts from 1979 to 1988 to develop a climatology of cyclogenesis in the South American region. Their study found two main genesis regions on the eastern coast of South America: one in southeast Argentina and another above Uruguay. By using vorticity instead of the pressure field, more recent works found a third genesis region on the southeastern Brazilian coast (Sinclair, 1995; Hoskins and Hodges, 2005; Reboita et al, 2010a).

The southeastern coast of Argentina, around $45^{\circ} \mathrm{S}$, is the most active cyclogenesis region (Hoskins and Hodges, 2005). High values of genesis are found year round, but in the summer the occurrence of cyclogenesis is largest. For the Uruguay genesis $\left(30^{\circ} \mathrm{S}\right)$ the most active period is during winter. Gan and 
Rao (1991) also found the same cyclone genesis for the Argentina and Uruguay regions. The third cyclogenesis region is most active during the austral summer on the southeastern Brazilian coast (Hoskins and Hodges, 2005; Reboita et al, 2010a). Hoskins and Hodges (2005) described the last two regions as subtropical paths of the South Atlantic storm track owing to their occurrence at lower latitudes than the main storm track of the Southern Hemisphere.

The development of cyclones along the South American coast is related mainly to the high and mid-level transient troughs from the Pacific and their interaction with the stationary Andes trough (Gan and Rao, 1994; Vera et al, 2002). Mendes et al (2007) showed that the Andes Cordillera not only fosters cyclonic anomalies through lee effects but is also conducive to channeling tropical moist and warm air to subtropical latitudes generating moisture convergence at the surface. Mid-level ascent may enhance this low-level convergence promoting latent heat release due to precipitation (Vera et al, 2002).

Ocean conditions can also influence cyclogenesis along the South American coast. Vera et al (2002) suggest that the warm waters of the Brazil Current provide moisture and heat that reduces the static stability at low levels. Besides this, the presence of the Brazil-Malvinas Confluence near $38^{\circ} \mathrm{S}$ (Gordon, 1989 ) is responsible for introducing high Sea Surface Temperature (SST) gradients that can generate low-level baroclinicity (Sanders and Gyakum, 1980) promoting cyclogenesis or intensification of cyclones.

Global and hemispheric scale studies have shown cyclone spatial distributions but generally, do not allow a detailed focus on the regional features of cyclones and the storm tracks. Some studies concerning cyclones and their evolution have focused on the South Atlantic, but have usually been restricted to South America (Gan and Rao, 1991, 1994; Mendes et al, 2010; Vera et al, 2002; Reboita et al, 2010a) or individual case studies (Seluchi and Saulo, 1998; Funatsu et al, 2004; Piva et al, 2008, 2010, 2011; Iwabe et al, 2011; Dias Pinto and Da Rocha, 2011; Dias Pinto et al, 2013; Gozzo and da Rocha, 2013; Dutra et al, 2017). These studies provide insights into the development of cyclones in South America but do not provide a climatological view of the forcing mechanisms acting on cyclones over the South Atlantic Ocean.

The primary aim of this work is to produce a new climatology of cyclones in the South Atlantic region that can provide new insights into the conditions leading to genesis in different regions of the South Atlantic. Considering the large latitude range and the seasonal variability of cyclogenesis in the South Atlantic science questions addressed in this paper are:

- What are the main forcing mechanisms that control cyclone development in each genesis region of the South Atlantic in their most active season?

- Are there any differences in the genesis precursors and structures of intense cyclones that originate in distinct genesis regions?

The answers to these questions will not only confirm the traditional perspectives of South Atlantic cyclones (e.g., track and genesis density) but also the spatial distribution and genesis characteristics of South Atlantic cyclones 
through composites of samples of cyclones as already performed for North Atlantic cyclones by Dacre and Gray (2009) and Catto et al (2010).

The paper continues in section 2 with a description of the data and methodology used and the challenges of tracking cyclones over the South American continent. In section 3 the cyclone density statistics are discussed including the spatial distribution of cyclone characteristics at genesis time in section 4 and the cyclone structure composites in section 5. Finally, a summary and final remarks are made in section 6 .

\section{Data and Methods}

In order to answer the scientific questions, cyclones will be directly identified and tracked in data from a modern reanalysis with the tracks then synthesized into statistical diagnostics for further analysis of their distribution and properties. The composites of the cyclone structure will also be done to provide a better understanding of cyclone genesis precursors for each region of interest.

\subsection{Datasets}

For this study, we used 32 years (1979-2010) of 6 hourly data from the Climate Forecast System Reanalysis produced by the National Centers for Environmental Prediction (NCEP CFSR; Saha et al, 2010). The NCEP-CFSR is an improvement on its older predecessors, NCEP-NCAR and NCEP-DOE, also produced by NCEP in terms of model formulation and resolution and data assimilation. The NCEP-CFSR includes coupled atmosphere, ocean, and land models, an interactive sea-ice model, assimilation of satellite radiances, and a significant increase in horizontal and vertical resolution of the atmospheric spectral model compared to the earlier NCEP reanalyses (Saha et al, 2010).

The atmospheric component is the Global Forecast System (GFS; Saha et al, 2010), which is a spectral model with a resolution of T382 $(38 \mathrm{~km})$ with 64 hybrid vertical levels extending from the surface to $0.26 \mathrm{hPa}$. The ocean model is the Geophysical Fluid Dynamics Laboratory (GFDL) Modular Ocean Model version 4 (MOM4; Griffies et al, 2004) with 40 vertical levels and a zonal resolution of $0.5^{\circ}$ and a meridional resolution of $0.25^{\circ}$ between $10^{\circ} \mathrm{N}$ and $10^{\circ} \mathrm{S}$ that gradually increases to $0.5^{\circ}$ poleward of $30^{\circ} \mathrm{N}$ and $30^{\circ} \mathrm{S}$. The NOAH land model (Ek et al, 2003) includes four soil layers and the ice model (Griffies et al, 2004) has two layers to account for variations below the surface.

Studies have shown that the latest set of reanalyses is a significant improvement over earlier reanalyses (e.g., Saha et al, 2010; Hodges et al, 2011; Stopa and Cheung, 2014), especially in the Southern Hemisphere. New data assimilation techniques and new sources of observational data (e.g., satellite, ARGO floats) have played an enormous role in the better representation of atmospheric features of regions where the observational network previously had poor coverage, such as in the SH. 
Stopa and Cheung (2014) showed that NCEP-CFSR represents global wind patterns in agreement with observed seasonal variability from buoy data and satellite products. These authors also recommend the use of the NCEP-CFSR for extreme event analysis. While other reanalyses underestimate extreme events, the NCEP-CFSR tends to overestimate them. Moreover, NCEP-CFSR was evaluated by Hodges et al (2011) in a study of extratropical cyclones. They compared four reanalyses regarding their ability to represent genesis and track density, maximum intensity and surface structure of extratropical cyclones. The ERA-Interim (ECMWF) and NCEP-CFSR have similar results, especially representing cyclogenesis associated with orography. The NCEP-CFSR also shows the most intense systems, which reinforces the findings from Stopa and Cheung (2014).

\subsection{TRACK Algorithm}

The tracking of cyclonic features is performed using the automated tracking system, TRACK, of Hodges $(1994,1995)$ using the relative vorticity field at $850 \mathrm{hPa}$ computed from the $\mathrm{U}$ and $\mathrm{V}$ winds. Usually, surface cyclone tracking is done using mean sea level pressure (MSLP; e.g., Murray and Simmonds, 1991) but, the relative vorticity permits the detection of weak and fast moving synoptic systems that can be masked by the background flow when using MSLP (Sinclair, 1994). Between $40^{\circ} \mathrm{S}$ and $20^{\circ} \mathrm{S}$, the surface pressure gradient is strong and cyclones may not have a closed isobar until they reach higher latitudes or intensify. Because of this, the use of relative vorticity also allows the detection of the cyclones in their earlier stages, when a closed isobar is not present (Sinclair, 1994). For these reasons, to consider cyclones in the South Atlantic sector the use of vorticity may be a better choice rather than MSLP, as discussed by Sinclair (1994) and Hoskins and Hodges (2002).

Although vorticity has been selected for this study, it contains much small scale structure at the resolution of NCEP-CFSR which can cause problems of coherence when attempting to track features at the synoptic scale. However, the vorticity can be filtered to reduce the small spatial scales and focus on the synoptic scales to avoid problems during the identification process and tracking. The vorticity is spectrally filtered by converting to the spectral representation and truncating to T42 and tapering the spectral coefficients to smooth the data. The large-scale background is also removed by setting total wavenumbers $\leq 5$ to zero. For more details of the filtering see Hoskins and Hodges (2002). Cyclones are identified by determining the local minima (cyclones have negative vorticity in the $\mathrm{SH}$ ) on a polar stereographic projection, which is important to prevent a latitudinal bias (Sinclair, 1997), that are less than a threshold of $-1.0 \times 10^{-5} s^{-1}$. The locations are refined by determining the off-grid locations using B-spline interpolation and steepest descent minimization, which results in smoother tracks.

The tracking is performed by first initializing a set of tracks by linking the detected feature points into tracks using the nearest neighbor method. 
The tracks are refined by minimizing a cost function for the track smoothness, which operates both forwards and backwards in time, subject to adaptive constraints on the maximum displacement in a time step and the track smoothness (Hodges, 1999). Only systems that last longer than 24 hours (4 time-steps) and have displacement from start to end greater than $1000 \mathrm{~km}$ are considered for further analysis. The use of the 24 hours lifetime threshold rather than 48 hours was based on previous regional studies of the Southwestern South Atlantic Ocean (e.g., Reboita et al, 2009; Reboita et al, 2018; Krüger et al, 2012). Reboita et al (2009) showed that most cyclones in this area exist between 1-2 days, as well as when only intense cyclones are considered $\left[\zeta \leq-2.5 \times 10^{-5} s^{-1}\right.$, $10-\mathrm{m}$ wind vorticity]. Even with the short lifetime, these systems can promote strong winds, which are important for wave generation and precipitation.

\subsection{Validation and applied constraints}

The tracking constraints adopted here differ from those used by Hoskins and Hodges (2002) and are presented in Table 1. The tracking results were compared to the synoptic charts from the Brazilian Navy from the summer (DJF) and winter (JJA) of 2005. Manual analysis was done to see if the algorithm captured cyclonic systems that influence the South American coast during the above period. However, it is important to be aware that a direct comparison between MSLP synoptic charts and the relative vorticity automated method will not necessarily have a one to one correspondence due to the different nature of the fields, as already discussed in section 2.2 (Sinclair, 1997; Hoskins and Hodges, 2002).

The narrow shape of South America south of $30^{\circ}$ allows the algorithm with the standard settings for extra-tropical cyclones to connect some tracks coming from the Pacific with tracks in the South Atlantic. The spurious tracks crossing Andes Cordillera, remove genesis events of cyclones that develop near the Eastern South American coast, between $40^{\circ} \mathrm{S}$ and $20^{\circ} \mathrm{S}$. We solve this issue by adding a rectangular region over the Andes, where the cyclones are restricted to have a maximum displacement of $1^{\circ}$ (geodesic) in one-time step (Table 1). In this way, a cyclonic feature on the west side of South America cannot be linked with a feature on the east side of the Andes in the next time step, because the distance between the two features is larger than $1^{\circ}$. Also, we reduce the maximum displacement to $4^{\circ}$ per time step between $30^{\circ} \mathrm{S}$ and $20^{\circ} \mathrm{S}$ to inhibit the connection between thermal lows above the continent with cyclogenesis at the coast.

Finally, we relax the constraints that allow changes in velocity (speed and direction) for slow moving systems to include in the tracking some cyclones at the Southeastern South American coast that present a quasi-stationary behavior at some stages of their lifecycle or abrupt change in their propagation direction (Dias Pinto et al, 2013; Dutra et al, 2017). These slow moving systems spend some days close to the coast before they propagate southeastward, causing strong winds and precipitation on the continent. During the validation 
Table 1 Adaptive constraints used by Hoskins and Hodges (2005) and in the present work. The last column indicates the allowed maximum displacement per time-step in each zone

\begin{tabular}{cccc}
\hline \multicolumn{4}{c}{ Zonal Upper-bound displacements } \\
& Longitude & Latitude & $d_{\max }($ degree) \\
\hline \hline Hoskins and & $0-360$ & $-90--20$ & 6.5 \\
Hodges 2005 & $0-360$ & $-20-0$ & 3.0 \\
\hline Present work & $0-360$ & $-90--45$ & 6.5 \\
& $0-285$ & $-45--30$ & 6.0 \\
& $285-295$ & $-45--30$ & 1.0 \\
$295-360$ & $-45--30$ & 6.0 \\
& $0-360$ & $-30--20$ & 4.0 \\
$0-360$ & $-20-0$ & 3.0 \\
\hline
\end{tabular}

process, a set of tests was performed to find the configuration that best solves these problems without interfering with the algorithm performance. This new setup provided an $89 \%$ agreement with the synoptic chart analysis.

\subsection{Diagnostics}

The spatial statistics are produced by the TRACK code using the spherical kernel method (Hodges, 1996). The cyclogenesis density is computed using the starting point of each track, excluding the tracks that start at the first time step of the analysis period. In the same way, lysis density is calculated using the end point of the track and do not consider tracks that end in the last time step of the analysis period. Track density is computed using a single point from each track closest to the estimation points. The raw density statistics are scaled to number densities per month per unit area. The area unit is equivalent to a $5^{\circ}$ spherical cap, which is approximately $10^{6} \mathrm{~km}^{2}$.

Besides the traditional statistics, other meteorological fields were added to the tracks to provide more information about the genesis environment, life cycle characteristics and vertical structure of the identified cyclones. This additional information can be added by searching for a maximum, minimum or average value within a radius from the tracked center at each time step. Statistical diagnostics are computed from these additional fields in terms of histograms and spatial distributions at a given time (e.g., maximum intensity). The spatial distributions of genesis characteristics have been produced by averaging the genesis characteristics (e.g., MSLP) of all cyclones generated within a $10^{6} \mathrm{~km}^{2}$ area.

The first additional fields added to the tracks are the MSLP and the maximum wind speed at $925 \mathrm{hPa}$ for the evaluation of the mean and maximum intensity of the cyclones. Both fields are available in NCEP-CFSR and, no further calculation was required. The minimum MSLP was sampled within a radius of $5^{\circ}$ (geodesic) from the tracked center and the maximum wind speed at $925 \mathrm{hPa}$ within a radius of $6^{\circ}$. Another way to measure intensity is using 
the precipitation associated with the cyclone, which was computed as an area average within $6^{\circ}$ using the NCEP-CFSR precipitation.

Other fields were added to the tracks to analyze further the cyclone development characteristics, all of them averaged within $5^{\circ}$ of the cyclone centers. These additional fields are the mean upper-level jet velocity to evaluate upper-level atmospheric environments and the sea surface temperature gradient, static and conditional stability and integrated specific humidity to analyze the lower level atmospheric environment. The mean upper-level jet velocity was obtained through a weighted vertical average of velocity at each level between 100 and $500 \mathrm{hPa}$. The vertical stabilities and integrated humidity were computed using the layers between $1000 \mathrm{hPa}$ and $700 \mathrm{hPa}$. The static stability was estimated by the potential temperature lapse-rate $\left(\Gamma=\frac{\delta \theta}{\delta p}\right)$, while conditional stability was obtained using the equivalent potential temperature lapse-rate $\left(\Gamma_{e}=\frac{\delta \theta_{e}}{\delta p}\right)$, where $\theta_{e}$ is computed using the formulation of Bolton (1980).

\subsection{Compositing of cyclones structure}

To study the structure of the cyclones, compositing of the $30 \%$ most intense cyclones from each cyclogenesis region were considered to produce a more homogeneous group regarding their evolution. The cyclogenesis regions are defined through the genesis density distributions that are presented in section 3.2 and the intensity threshold applied to identify the most intense cyclones is discussed in section 5 .

The compositing method used here was first used by Bengtsson et al (2007) to study tropical cyclone structure. After that, several works applied the same method to study extratropical cyclone structures (Bengtsson et al, 2009; Catto et al, 2010; Hodges et al, 2011; Dacre et al, 2012). This method consists of sampling the required field (e.g., MSLP, $\theta_{e}$ ) using a radial grid centered at the cyclone center for each time step along its track. The radial grid is of a size 20-degree radius with a 0.5-degree grid spacing, both azimuthally and radially. The composites are produced by averaging the fields on the radial grid at each offset time relative to the genesis (the first point where the cyclone was detected). In previous works, the grid is rotated according to the cyclone propagation direction, what allows the system-relative winds to be analysed (e.g., air-flows inside the cyclone). However, this step was not adopted here because a non-rotated grid allows an assessment of the features relative to geographic coordinates and features that impact genesis that is relevant to the study of genesis precursors in South America. Times earlier than cyclogenesis are also considered to analyze the dynamic and thermodynamic features that lead to genesis. If the time of interest is before the time of genesis, the sampling was made using the position of the cyclone at the genesis time applied at the earlier time.

Besides the traditional meteorological fields (e.g., sea level pressure, geopotential), other derived fields were used for the compositing. The variables were calculated on a hemispheric grid $\left(0^{\circ}-90^{\circ} \mathrm{S}\right)$ for each time step before being sam- 
pled for the compositing. The relative humidity is estimated for a given temperature, mixing ratio, and pressure, using a look-up table procedure (Murray, 1967). The vertically integrated moisture flux convergence (VIMFC) is used as a measure of the lower tropospheric forced lifting. In this study, the VIMFC is defined as the horizontal moisture flux convergence integrated between 1000 $\mathrm{hPa}$ and $700 \mathrm{hPa}$ :

$$
V I M F C=-\frac{1}{g} \int_{700 h P a}^{1000 h P a}\left(\frac{\partial u q}{\partial x}+\frac{\partial v q}{\partial y}\right) d p
$$

where $g$ is the gravitational acceleration, $u$ and $v$ are the zonal and meridional component of the velocity, respectively, and $q$ is specific humidity. Also, the vertically integrated moisture transport (VIMT) was computed in a similar way

$$
\overrightarrow{V I M T}=-\frac{1}{g} \int_{700 h P a}^{1000 h P a}(u q \vec{i}+v q \vec{j}) d p
$$

The VIMT has zonal and meridional components. The temperature advection at $850 \mathrm{hPa}$ and the mass divergence at 200 and $300 \mathrm{hPa}$ were computed using centered finite differences for the partial derivatives. The potential vorticity (PV) at $300 \mathrm{hPa}$ was computed on isobaric levels $(p)$ on a global grid, following Bluestein (1992) (page 264, Eq. 4.5.93).

\section{Cyclone density statistics}

In this section, the spatial statistics are first considered to provide information on the general distribution of the cyclones and their seasonal variation. These statistics provide us with the typical cyclogenesis regions within the South Atlantic, which is going to be used as a guide to understanding differences in genesis environment and structure of cyclones in the domain.

\subsection{Track Density}

The cyclone track density is shown in Figs.1a and b for the austral summer (DJF) and winter (JJA), respectively. This shows there is a region of maximum track density extending from west to east between $40^{\circ} \mathrm{S}$ and $55^{\circ} \mathrm{S}$ [>10 cyclones $\left(10^{6} \mathrm{~km}^{2}\right)^{-1}(\text { month })^{-1}$ ] which extends over a larger latitudinal range in the austral winter (JJA) than in the summer (DJF), this is the main South Atlantic storm track. There is also a secondary track density region [>6 cyclones $\left(10^{6} \mathrm{~km}^{2}\right)^{-1}$ (month) ${ }^{-1}$ ] extending southeastward from Uruguay and the South Brazilian coast, which seems to merge with the main southern storm track. This second storm track is considered to be a subtropical branch of the South Atlantic storm track (e.g., Hoskins and Hodges, 2005). During 


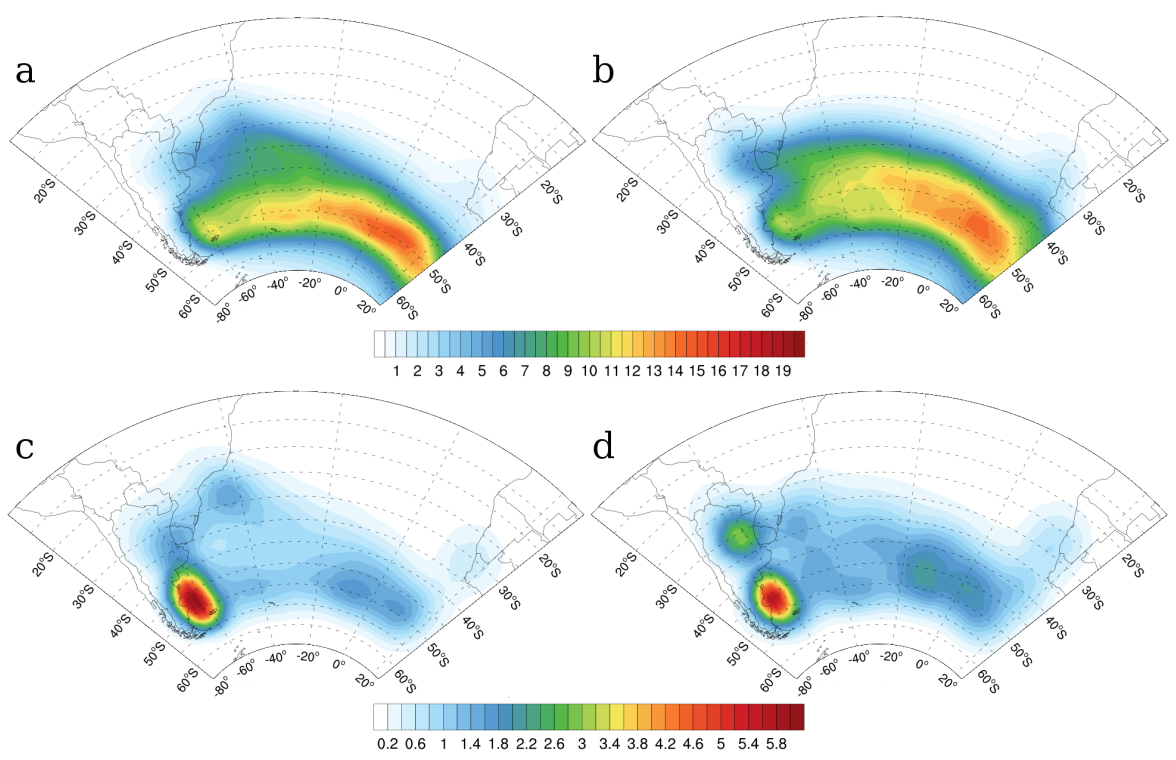

Fig. 1 The cyclone track density for the (a) summer (DJF) and (b) winter (JJA), and the genesis density for the (c) summer (DJF) and (d) winter (JJA). The densities are computed using only cyclones with the first time step within South Atlantic domain, in a box between $15^{\circ} \mathrm{S}-55^{\circ} \mathrm{S}$ and $75^{\circ} \mathrm{W}-20^{\circ} \mathrm{E}$. The density unit is cyclone per $10^{6} \mathrm{~km}^{2}$ per month.

the summer, this branch originates more northward $\left(30^{\circ} \mathrm{S}\right)$, while during the other seasons it starts between $30^{\circ} \mathrm{S}$ and $35^{\circ} \mathrm{S}$.

The pattern of track density and its variability throughout the year corresponds to that found in other studies (e.g., Taljaard, 1967; Sinclair, 1994; Hoskins and Hodges, 2005). However, there are some differences between studies associated with some studies using relative vorticity and studies based on MSLP or any field computed from the MSLP, e.g., geostrophic vorticity. For example, Simmonds and Keay (2000) found that in the South Atlantic Ocean sector the highest track density was around $60^{\circ} \mathrm{S}$ with no clear evidence of a subtropical storm track in their results. These differences are related to using MSLP to perform the cyclone tracking where the cyclones in the sub-tropics are weak and fast moving, and often do not have a closed isobar in their early stages due to the strong background pressure gradient at this location (Sinclair, 1994, 1995, 1997; Hoskins and Hodges, 2005).

\subsection{Genesis Density}

Figures $1 \mathrm{c}$ and d show the genesis density of cyclones originating in the South Atlantic domain in austral summer and winter respectively. There are three regions of high genesis along the South American East coast: the central Argentina coast between $55^{\circ} \mathrm{S}$ and $40^{\circ} \mathrm{S}$ (ARG, hereafter); Northeastern Ar- 


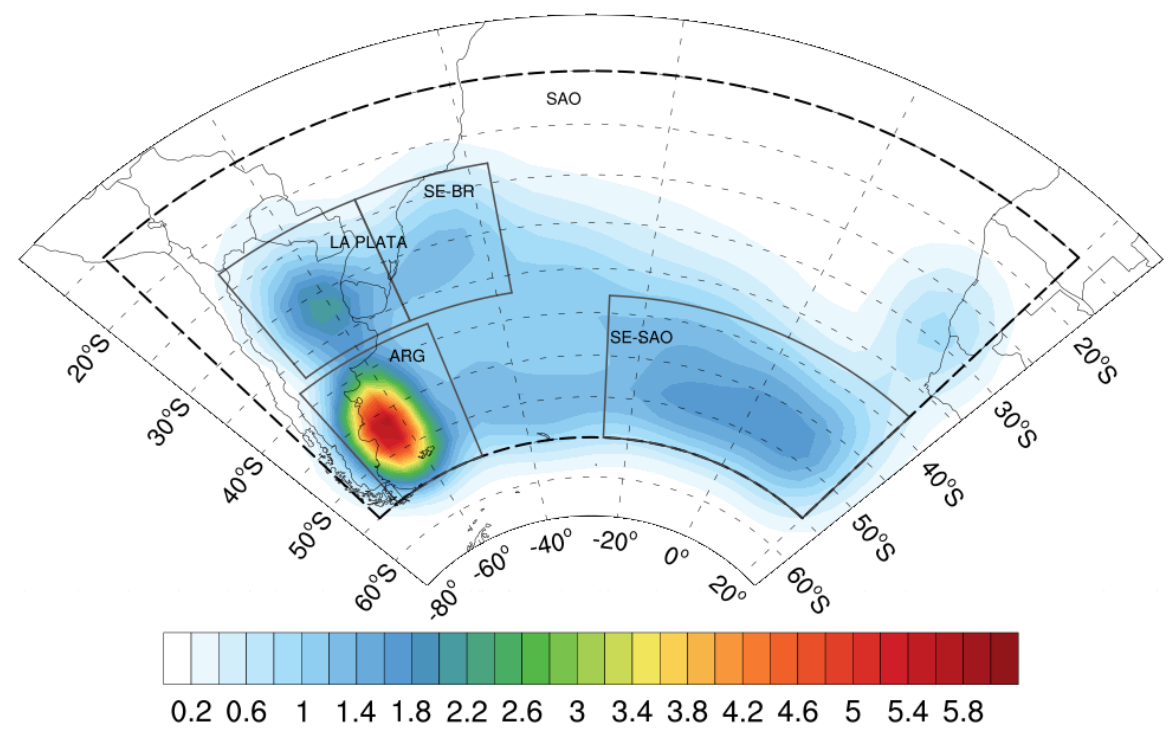

Fig. 2 Genesis density for South Atlantic domain (marked in dashed gray line) computed for the entire period of 1979-2010. The four genesis regions are marked in black line. The density unit is cyclone per $10^{6} \mathrm{~km}^{2}$ per month.

gentina and the Uruguay region, close to the La Plata river discharge at $30^{\circ} \mathrm{S}$ (LA PLATA, hereafter), and the South-Southeast coast of Brazil, between $30^{\circ} \mathrm{S}$ and $25^{\circ} \mathrm{S}$ in the summer and $35^{\circ} \mathrm{S}$ and $30^{\circ} \mathrm{S}$ in the winter (SE-BR, hereafter). A fourth genesis region can be seen in the Southeastern South Atlantic Ocean (SE-SAO, hereafter), centered at $45^{\circ} \mathrm{S}$ and $10^{\circ} \mathrm{W}$. Both the cyclogenetic regions at $50^{\circ} \mathrm{S}$ and $45^{\circ} \mathrm{S}$ are active throughout the year. Despite that, the ARG region presents slightly more genesis in summer and the SE-SAO in winter. A see-saw behavior is noted at the northward latitudes too. The LA PLATA region has more genesis in winter while the SE-BR genesis region is active in summer. The four main cyclogenesis regions that exist in the South Atlantic domain were selected based on the genesis density distribution, even if a genesis regions present high genesis density values only in one analyzed season. Figure 2 indicates the chosen sampling genesis regions. These regions are based on the genesis density computed for the whole 1979-2010 period and the boxes do not change according to the season. It is possible to note another high genesis density region along the western coast of South African and southern coast of Namibia, which is more intense during the winter. This cyclogenetic area is also reported by Hoskins and Hodges (2005) and, according to Inatsu and Hoskins (2004), it is driven by the South African Plateau. However, the genesis density in western South Africa is weak compared with the other regions described above, and it is not going to be included in this study. 
Table 2 Total number of cyclogenesis events, annual mean and standard deviation for South Atlantic domain $\left(15^{\circ} \mathrm{S}-55^{\circ} \mathrm{S}, 75^{\circ} \mathrm{W}-20^{\circ} \mathrm{E}\right)$ and in each preferred genesis region within the domain. The values were computed for the entire analysis period (1980-2010), summer (DJF) and winter (JJA).

\begin{tabular}{|c|c|c|c|c|c|c|}
\hline \multirow[b]{2}{*}{ region } & \multicolumn{2}{|c|}{19802010} & \multicolumn{2}{|c|}{$\overline{D J F}$} & \multicolumn{2}{|c|}{ JJA } \\
\hline & total & annual mean & total & annual mean & total & annual mean \\
\hline South Atlantic & 12754 & $411.4 \pm 10.2$ & 2950 & $95.2 \pm 6.4$ & 3476 & $112.1 \pm 7.6$ \\
\hline SE-BR & 856 & $27.6 \pm 2.2$ & 227 & $7.3 \pm 1.9$ & 201 & $6.5 \pm 2.4$ \\
\hline LA PLATA & 1157 & $37.3 \pm 3.1$ & 224 & $7.2 \pm 2.2$ & 351 & $11.3 \pm 3.0$ \\
\hline $\mathrm{ARG}$ & 2972 & $95.9 \pm 4.6$ & 831 & $26.8 \pm 4.0$ & 712 & $23.0 \pm 4.5$ \\
\hline SE-SAO & 3666 & $118.3 \pm 5.8$ & 804 & $25.9 \pm 4.1$ & 1081 & $34.9 \pm 5.6$ \\
\hline
\end{tabular}

Table 2 shows the number of genesis events for each defined region per season. The ARG and SE-SAO region are together responsible for $50 \%$ of genesis within the South Atlantic Ocean. Both of them are located in the main storm track latitude zone (Figs.1a and b). Looking at the number of cyclones in each region in different seasons it is possible to see that there is no strong seasonal variability in some regions, such as SE-BR and ARG. In fact, these two regions have less than $20 \%$ more cyclones in summer than in the winter. Through the genesis density map, the SE-BR region seems to be more concentrated northward of $30^{\circ} \mathrm{S}$ in the summer giving the idea of more genesis. For the LA PLATA and SE-SAO regions, there is a significant increase of genesis in the winter of $56 \%$ and $34.5 \%$ of cyclones, respectively. Regarding the differences in cyclone identification and tracking methods described above, it is difficult to compare the seasonal variability of genesis in specific regions from other studies as these have used different region boundaries to compute such variability (e.g., Reboita et al, 2010a).

The pattern of genesis densities compares well with those produced by other studies (Hoskins and Hodges, 2005; Reboita et al, 2010a; Hodges et al, 2011). The SE-SAO region is within the main South Atlantic storm track though has not often been discussed in previous studies. Hoskins and Hodges (2005) included the storm path originating from this region showing that SE$\mathrm{SAO}$ is located at the end of the storm path from the eastern South American coast suggesting a downstream development in this region. Trenberth (1991) and Berbery and Vera (1996) studied the SH storm track using an Eulerian approach and also found evidence of cyclone development in this region.

The differences in the magnitudes of genesis between this work and some previous studies (e.g., Gan and Rao, 1991; Sinclair, 1994, 1995; Hoskins and Hodges, 2005; Reboita et al, 2010a; Mendes et al, 2010) can be generally explained by the field used to do the tracking, the feature identification thresholds (e.g., lifetime, minimum intensity), the method used to compute the statistics and even by the resolution of the data used. Gan and Rao (1991) and Mendes et al (2010) produced genesis density maps based on cyclone identification using the MSLP with manual and automated tracking methods, respectively. Both of them found two main cyclogenesis regions on the 


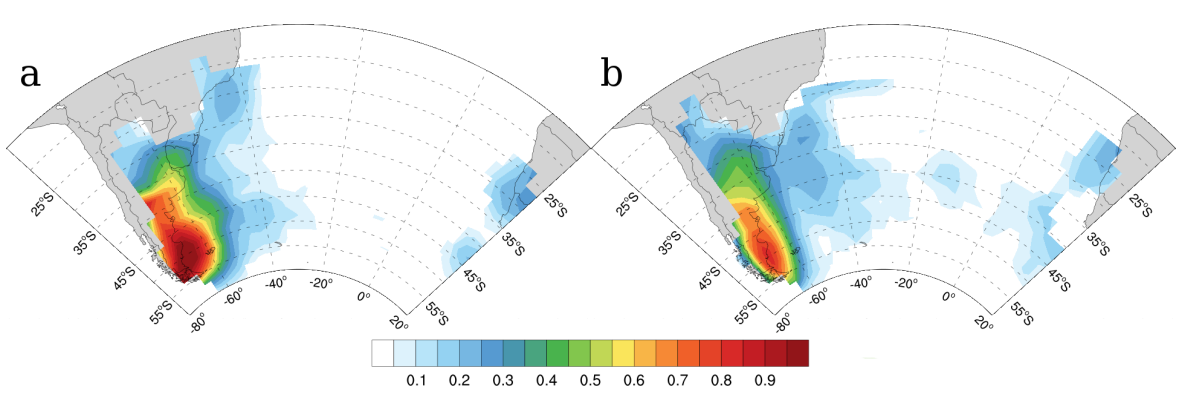

Fig. 3 Mean growth rate $\left(10^{-5} s^{-1} d a y^{-1}\right)$ for the (a) summer (DJF) and (b) winter (JJA) computed using only cyclones with the first time step within South Atlantic domain, in a box between $15^{\circ} \mathrm{S}-55^{\circ} \mathrm{S}$ and $75^{\circ} \mathrm{W}-20^{\circ} \mathrm{E}$.

South American coast equivalent to the LA PLATA and ARG genesis region of this work. Sinclair (1995) and Hoskins and Hodges (2005) using methods based on relative vorticity found a third region at $25^{\circ} \mathrm{S}$, suggesting that cyclones developing in the SE-BR region were weak systems that may not be detected by the use of MSLP as discussed earlier. There are also differences between studies based on vorticity computed from the winds at a tropospheric level above the boundary layer, e.g., $850 \mathrm{hPa}$ (this study, Hoskins and Hodges, 2005) and those based on computing vorticity from $1000 \mathrm{hPa}$ geopotential or MSLP (e.g., geostrophic vorticity Sinclair, 1994, 1995). Although weak and fast moving systems from subtropical latitudes are presented in the cyclogenesis distribution maps of Sinclair $(1994,1995)$, there is an underestimation when compared with this work and other studies based on relative vorticity from winds (Hoskins and Hodges, 2005; Reboita et al, 2010a). Reboita et al (2010a) used vorticity from winds at $10 \mathrm{~m}$, and an intensity threshold of $-1.5 \times 10^{-5} s^{-1}$ and considered only cyclones with the first time point of the track above the ocean. These authors found three genesis regions along the South American coast, similar to our finding, although the regions above the continent (LA PLATA) appears shifted to the coast at $35^{\circ} \mathrm{S}$. The comparison between Hoskins and Hodges (2005) and this study shows higher correspondence, probably due to the same tracking method based on relative vorticity of winds at $850 \mathrm{hPa}$ albeit using different reanalyses. However, here, the mean genesis density is higher in some locations when compared with Hoskins and Hodges (2005). The genesis magnitude is much higher on the Argentina coast and it is slightly higher in the SE-BR region for both seasons. The newly applied tracking constraints may be responsible for the accumulation of genesis densities, although the shorter lifetime threshold is probably the main reason for these differences. While we are using 24 hours, Hoskins and Hodges (2005) considered tracks that last more than 48 hours. Comparing genesis densities computed for cyclones that last more than $48 \mathrm{~h}$ (not shown) with the results in Figs. 1c and d, it is possible to see an increase in the genesis density in the SE-BR and ARG regions, particularly in the summer, and in SE-SAO region. 
It is important to note that here we define genesis as the first appearance of so the cyclone at low levels, i.e., the first point identified by the algorithm. Grise 451 et al (2013) argue that this definition may introduce some artificial features ${ }_{2} 2$ into the genesis distribution, particularly on the lee side of mountain chains. ${ }_{43}$ These authors deal with this issue by adding a minimum growth rate criteria 454 of $2 \times 10^{-5} s^{-1} d a y^{-1}$ to select developing cyclones and showed that along 455 the U.S. Southeastern coast, over the Gulf Stream, the cyclone development is 46 greater than in the lee of the Rockies. Following Grise et al (2013) method, the 47 high genesis usually seen along the eastern side of the Rockies Mountains by 458 several authors (e.g., Hoskins and Hodges, 2002; Dacre and Gray, 2009) would 459 be a bias caused by the intersection of the $850 \mathrm{hPa}$ level and the orography. so However, Fig.3, which shows the mean growth rate for the summer and winter, 461 shows that the maximum values occur on the lee side of Andes, in agreement with the genesis density in Figs. 1c and d. The large values of mean growth rate on the lee side enhance the evidence of genesis at this location rather than a methodology issue. Moreover, Grise et al (2013) define genesis as a developing phase, and their method allows a single cyclone to be counted more than once in their density statistic if it has more than one developing 17 phase during its lifetime. This criterion may be useful to study fast growing cyclones and intensification regions, but it may make it difficult to isolate the precursor of a surface cyclone development in its earliest stages, as we aim in this work.

\subsection{Intensity, lifetime and duration if the cyclones}

Figure 4 shows the histogram of relative vorticity from cyclones at their genesis time for summer and winter in the South Atlantic region. The starting vorticity of a cyclone may be important to estimate its impacts on the continent, considering that three main cyclogenesis regions of the domain are located near the coast and big cities. The frequency in Fig. 4 is displayed as a percentage to a better comparison between the genesis regions. The vorticity is scaled by -1 . The SE-BR and LA PLATA cyclones present a similar distribution of initial vorticity, with a peak between -2 and $-3 \times 10^{-5} s^{-1}$ in the summer, corresponding to $36.5 \%$ and $42.9 \%$ of their systems, respectively. However, in the winter, SE-BR cyclones present a big group of systems (20.0\%) with initial vorticity between -4 and $-6 \times 10^{-5} s^{-1}$. The ARG cyclones present less intense cyclones at the time of genesis in the summer, being almost $44.3 \%$ of its systems between -1 and $-2 \times 10^{-5} s^{-1}$. The SE-SAO region has a higher frequency of cyclones with higher intensity at genesis time in both seasons. The majority of the South Atlantic cyclones have the starting cyclonic vorticity weaker in summer than winter. The mean intensity at genesis time is $-2.8 \pm 1.4 \times 10^{-5} s^{-1}$ in summer and $-3.4 \pm 1.6 \times 10^{-5} s^{-1}$ in winter (Table 3 ). The SE-SAO region has higher intensity at genesis time when compared to the other regions, reaching a mean of $-4.0 \pm 1.9 \times 10^{-5} s^{-1}$ during winter (Table 3 ). The high initial vorticity of the SE-SAO region reinforces the idea of down- 

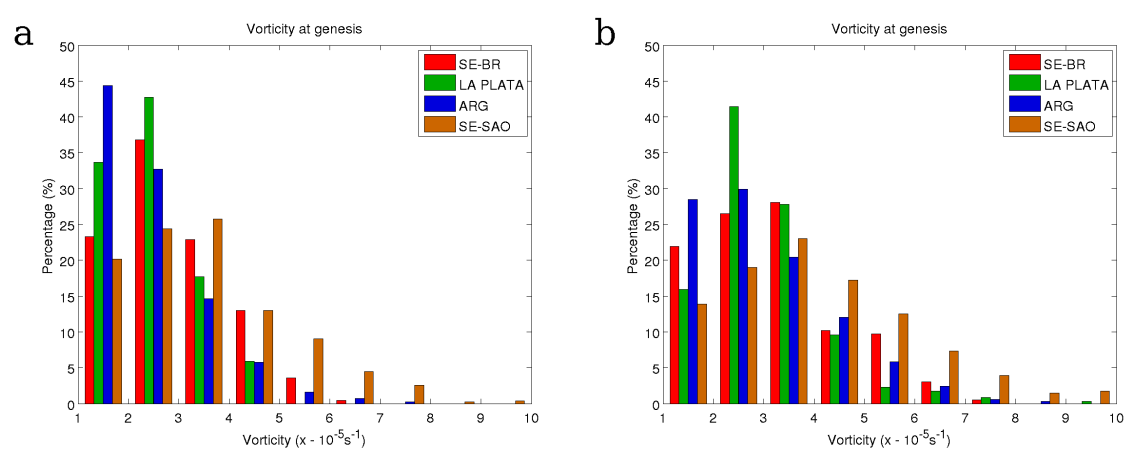

Fig. 4 Histograms of the vorticity at the genesis time in the (a) summer and (b) winter for the cyclones which originate in SE-BR (red), LA PLATA (green), ARG (blue) and SE-SAO (orange) regions. The relative vorticity is scaled by $-1 \times 10^{-5} s^{-1}$ and the $y$-axis shows the percentage computed based on the total number of cyclones detected in each defined genesis region.

stream development mechanisms (e.g., Orlanski and Katzfey, 1991) or other secondary genesis mechanisms. The mean growth rate in the SE-SAO region is weaker than in other genesis regions - only a weak signal in the winter in Fig. 3 - which shows that the cyclogenesis in this region occurs associated with a pre-existing cyclone. It is important to clarify that the location of the SESAO region within the main South Atlantic storm track may lead to spurious tracks as results of tracking issues related to the separation of one storm into two separate storms. This problem is more likely to occur within regions where there are occluding cyclones. The South Atlantic domain presents low values of cyclolysis density (when compared with genesis) and cyclone occlusion occurs widespread across the basin, including the SE-SAO region, and concentrated near Antarctica (not shown). Therefore, this problem could happen in any location of the study domain and would not influence the genesis only in this area.

Table 3 contains the mean relative vorticity at genesis time, mean lifetime and mean cyclone displacement speed in each defined genesis region computed for the whole period, and separately for summer and winter. The mean lifetime of South Atlantic cyclones is longer in the summer (4.1 \pm 2.9 days) than in winter (3.7 \pm 2.4 days). The region that presents the longest lifetime is the LA PLATA region (5.4 \pm 2.9 days in summer). The SE-SAO has the shortest duration systems ( $3.4 \pm 2.4$ days) for the whole period. In general, South Atlantic cyclones tend to be slightly faster in the winter $\left(15.7 \pm 4.9 \mathrm{~m} \mathrm{~s}^{-1}\right.$ against $14.4 \pm 4.6 \mathrm{~m} \mathrm{~s}^{-1}$ in the summer). ARG and SE-SAO regions present the highest displacement speed due to the large-scale flow dominated by the westerlies. The mean values presented in Table 3 are higher when compared with other South Atlantic climatologies. Reboita et al (2009), using 10 years of NCEP-DOE (Kanamitsu et al, 2002), found a mean speed of $11.0 \mathrm{~m} \mathrm{~s}^{-1}$, a mean lifetime of 2.6 days and an initial vorticity of $-2.5 \times 10^{-5} s^{-1}$. These 
Table 3 The mean $850 \mathrm{hPa}$ relative vorticity at genesis time (scaled by $-1 \times 10^{-5} s^{-1}$ ), mean lifetime (days) and mean cyclone displacement speed $\left(\mathrm{ms}^{-1}\right)$ and standard deviations computed within South Atlantic domain $\left(15^{\circ} \mathrm{S}-55^{\circ} \mathrm{S}, 75^{\circ} \mathrm{W}-20^{\circ} \mathrm{E}\right)$ and within each defined genesis region. The means were calculated for the whole analysis period (1980-2010), only for summer (DJF) and only for winter (JJA).

\begin{tabular}{rccc}
\hline \hline \multicolumn{4}{c}{$1980-2010$} \\
region & initial vort. & lifetime & speed \\
\hline \hline South Atlantic & $3.1 \pm 1.5$ & $3.9 \pm 2.7$ & $15.0 \pm 4.8$ \\
SE-BR & $3.0 \pm 1.3$ & $4.2 \pm 2.7$ & $13.2 \pm 4.7$ \\
LA PLATA & $2.7 \pm 1.1$ & $5.3 \pm 3.1$ & $12.6 \pm 3.8$ \\
ARG & $2.7 \pm 1.2$ & $4.0 \pm 2.6$ & $14.9 \pm 4.0$ \\
SE-SAO & $3.7 \pm 1.8$ & $3.4 \pm 2.4$ & $17.1 \pm 4.7$ \\
\hline \multicolumn{4}{c}{ DJF } \\
region & initial vort. & lifetime & speed \\
\hline \hline South Atlantic & $2.8 \pm 1.4$ & $4.1 \pm 2.9$ & $14.4 \pm 4.6$ \\
SE-BR & $2.9 \pm 1.1$ & $4.8 \pm 3.0$ & $12.1 \pm 4.2$ \\
LA PLATA & $2.4 \pm 0.9$ & $5.4 \pm 2.9$ & $12.2 \pm 3.7$ \\
ARG & $2.4 \pm 1.1$ & $4.3 \pm 2.9$ & $14.5 \pm 3.9$ \\
SE-SAO & $3.4 \pm 1.6$ & $3.7 \pm 2.6$ & $16.3 \pm 4.4$ \\
\hline & JJA & \\
region & initial vort. & life time & mean speed \\
\hline \hline South Atlantic & $3.4 \pm 1.6$ & $3.7 \pm 2.4$ & $15.7 \pm 4.9$ \\
SE-BR & $3.2 \pm 1.3$ & $3.5 \pm 2.2$ & $14.3 \pm 4.8$ \\
LA PLATA & $3.0 \pm 1.2$ & $5.1 \pm 3.0$ & $13.1 \pm 3.9$ \\
ARG & $3.0 \pm 1.4$ & $3.7 \pm 2.2$ & $15.2 \pm 4.1$ \\
SE-SAO & $4.0 \pm 1.9$ & $3.3 \pm 2.2$ & $17.6 \pm 4.8$ \\
\hline
\end{tabular}

differences can be understood by the NCEP-DOE lower resolution, but also by the fact that in Reboita et al (2009) the cyclones are tracked based on the vorticity computed from the $10 \mathrm{~m}$ winds. The cyclone structure at the surface is affected by drag, and the winds are weaker when compared with the 850 $\mathrm{hPa}$ field. Also, some disturbance can still be tracked at $850 \mathrm{hPa}$ that do not exist at the surface, resulting in the longer lifetimes reported in Table 3.

Figures 5 and 6 shows histograms of different types of cyclone intensity measures computed as the lifetime maximum or minimum value within the South Atlantic domain, defined as SAO in Fig. 2. The histograms of maximum intensity in terms of vorticity (Figs.5a and b) show that the cyclones from the LA PLATA region are the most intense within the South Atlantic Ocean, as also seen in terms of $925 \mathrm{hPa}$ wind speeds (Figs.6a and b). This characteristic is less clearly seen when considering MSLP (Figs.5c and d), as this field is more likely to be influenced by the large scale background and tends to focus on larger spatial scales. However, the LA PLATA and SE-BR regions show a small peak of intense cyclones centered at $945 \mathrm{hPa}$ in the winter for the MSLP. The vorticity maximum intensity distribution shows there are three peaks, indicating three groups of cyclones in the LA PLATA region. The first is between -3.5 and $-4.5 \times 10^{-5} s^{-1}$, the second is around $-9.5 \times 10^{-5} s^{-1}$, and a third peak around $-13.0 \times 10^{-5} \mathrm{~s}^{-1}$. They exist in both seasons, but in the winter their frequency is similar, showing an increase in more intense 
cyclones in this season. In the MSLP histograms, there are two peaks for the LA PLATA cyclones in the summer, and three peaks in the winter, including the one centered around $945 \mathrm{hPa}$. The SE-BR region shows maximum vorticity around $-4.5 \times 10^{-5} \mathrm{~s}^{-1}$ in the summer and between -2.5 and $-4.5 \times 10^{-5} \mathrm{~s}^{-1}$ in the winter, but the tail of the distribution shows an increase of strong systems in the winter. The similarity between the LA PLATA and SE-BR intensity distributions may be related to their proximity to each other, mainly in winter when these two regions are basically at the same latitude. Hence, they may have the same growth mechanisms that change according to the seasonal variability. The only difference is the presence of more weak systems in the SE-BR region, especially during winter. The cyclones from the ARG and SESAO regions have maximum intensity distributions similar to the distribution for cyclones from all of the South Atlantic. The distribution changes if the maximum intensity is considered to be within the South Atlantic Ocean or is outside the domain (not shown). Larger intensities for vorticity and MSLP are found if we take into account all track points instead of the point within the domain which is expected because cyclones that travel long distances and move poleward tend to become more intense (e.g., Hoskins and Hodges, 2005). The most affected distribution with the change of maximum intensity point selection is the SE-SAO region due to its proximity to the SAO domain boundary.

The histogram of maximum precipitation rate within the cyclone reveals that SE-BR and LA PLATA cyclones generate the most intense precipitation with a similar pattern (Figs.6 c and d). The cyclones in the ARG and SESAO regions show maximum precipitation distributions with fewer cyclones with precipitation above $20 \mathrm{~mm} \mathrm{day}^{-1}$ when compared to cyclones from all the South Atlantic domain. According to the intensity histograms, cyclones from the SE-BR and LA PLATA regions are associated with intense winds and precipitation. Most of these systems have a lifecycle confined near the Southeastern American coast (not shown). This fact is particularly important as even with a small number of cases per year these cyclones impact the coastal region directly.

\section{Spatial Distribution of cyclone properties}

The distribution of properties of South Atlantic cyclones is discussed in an attempt to understand the dynamical and thermodynamical spatial characteristics of cyclone development from a climatological point of view. Some of these distributions are shown as anomalies, computed as a deviation from the seasonal climatology.

The spatial distribution of the SST gradient at the time of genesis (Figs.7a and b) shows that between $30^{\circ} \mathrm{S}$ and $45^{\circ} \mathrm{S}$ cyclones develop in a high SST gradient environment (Sinclair, 1995; Hoskins and Hodges, 2005). Sinclair (1995) suggested that the correlation between high SST gradient and cyclogenesis may be related to the transfer of oceanic baroclinicity to the atmosphere. 

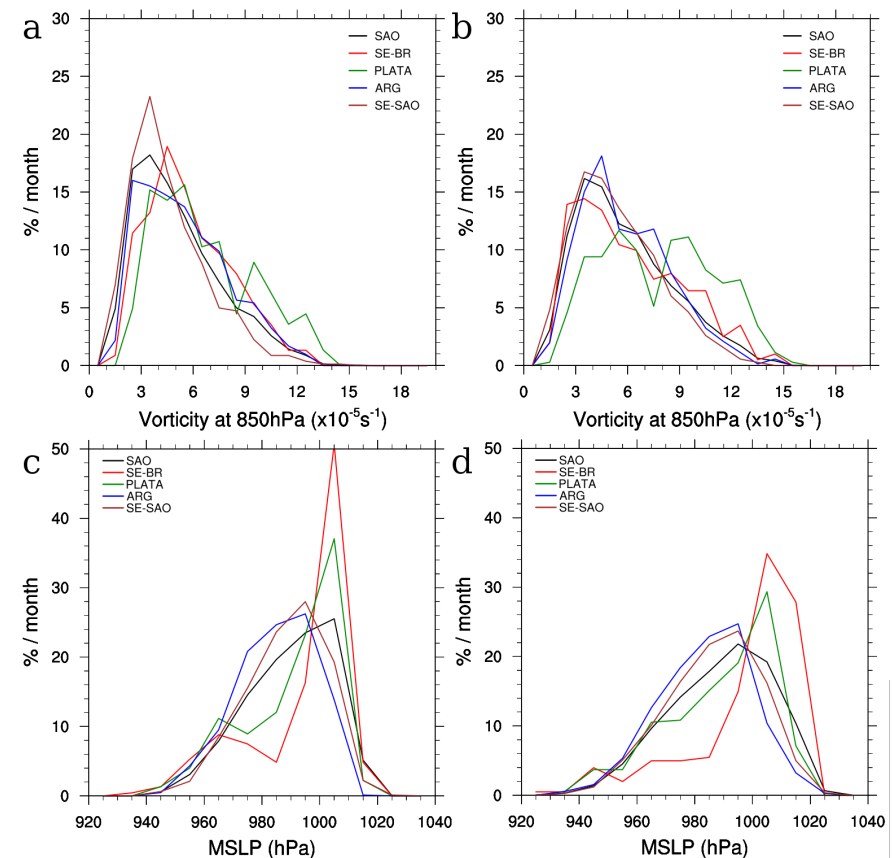

Fig. 5 Histograms of the maximum filtered vorticity at $850 \mathrm{hPa}$ in the (a) summer and (b) winter; and the MSLP (hPa) in the (c) summer and (d) winter, within South Atlantic domain. The vorticity is scaled by $-1 \times 10^{-5} \mathrm{~s}^{-1}$ and the MSLP minima was searched within $5^{\circ}$ radius from the center of the cyclone. The intensity histograms were produced for cyclones that originate in each genesis region separately. The percentage was computed based on the mean cyclones per month for each region: SE-BR (2.4), LA PLATA (2.4), ARG (8.9), SE-SAO (8.7) and for all South Atlantic domain (SAO; 31.72).

Comparing the track density (contours in Figs.7a and b) with the distributions of the SST gradient at the time of genesis it is possible to see that the position of the main South Atlantic storm track are related to high values of SST gradient at genesis time, as long as these high values are located on the equatorward flank of the storm track. The development of cyclones along the Southeastern South American coast appears to be associated with the presence of the high SST gradient environment that, in this location, is driven by the variability of the Brazil-Malvinas Confluence (BMC) and its associated fronts. During summer, the BMC is southward of its mean position affecting lower troposphere baroclinicity in the ARG region. In winter the confluence shifts northward reaching lower latitudes (Olson et al, 1988). Combined with the BMC shift, there is a northward intrusion of the La Plata River $\left(34^{\circ} \mathrm{S}\right)$ and Patos Lagoon $\left(32^{\circ} \mathrm{S}\right)$ discharge within the continental shelf off eastern South America during winter (Piola et al, 2000). The result is a cool SST tongue over the continental shelf that generates the subtropical shelf front (STSF) when it encounters the warmer waters of the Brazil Current (Fig.7d; Campos et al, 1999; Piola et al, 2000). The STSF and the BMC position in the winter affect 

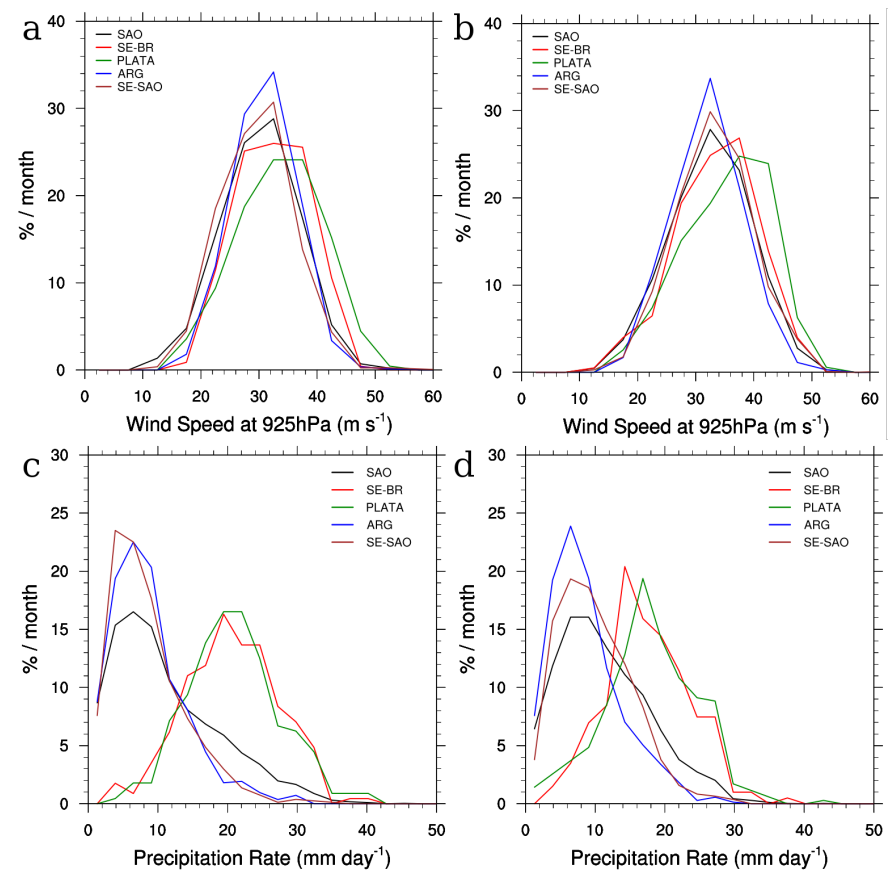

Fig. 6 Histograms of the maximum wind speed at $925 \mathrm{hPa}\left(m s^{-1}\right)$ in the (a) summer and (b) winter; and the precipitation rate $\left(m m d a y^{-1}\right)$ in the (c) summer and (d) winter, within South Atlantic domain. The maximum wind speed at $925 \mathrm{hPa}$ is searched within $6^{\circ}$ radius from the center of the cyclone and the precipitation is averaged within a $5^{\circ}$ radius. The intensity histograms were produced for cyclones that originate in each genesis region separately. The percentage was computed based on the mean cyclones per month for each region: SE-BR (2.4), LA PLATA (2.4), ARG (8.9), SE-SAO (8.7) and for all South Atlantic domain (SAO; 31.72).

the SST gradient at the time of genesis of the cyclones on the Southeastern South American coast, at $25^{\circ} \mathrm{S}-30^{\circ} \mathrm{S}$ (Fig.7b). Moreover, even cyclones that originate above the continent, in the LA PLATA region, are influenced by the increase of low-level baroclinicity as long as they move toward the ocean after genesis. The SST gradient at the time of genesis is weaker in SE-SAO, when compared with the other regions, what is in agreement with the low values of mean growth rate at this location (Fig. 3).

Figures $8 \mathrm{a}$ and $\mathrm{b}$ show the low level integrated humidity anomaly distribution at the time of genesis for the summer and winter, respectively. In both distributions, the humidity anomalies are positive in most parts of the domain, but mainly on the lee side of the Andes between $25^{\circ} \mathrm{S}$ and $40^{\circ} \mathrm{S}$ and in the $\mathrm{SE}-\mathrm{BR}$ region. These higher values of moisture at the time of genesis are a consequence of an intensified moisture flux from the South American low-level jet (SALLJ), on the eastern slope of the Andes, and from the South Atlantic Subtropical High (SASH), towards the southeastern coast (Marengo et al, 

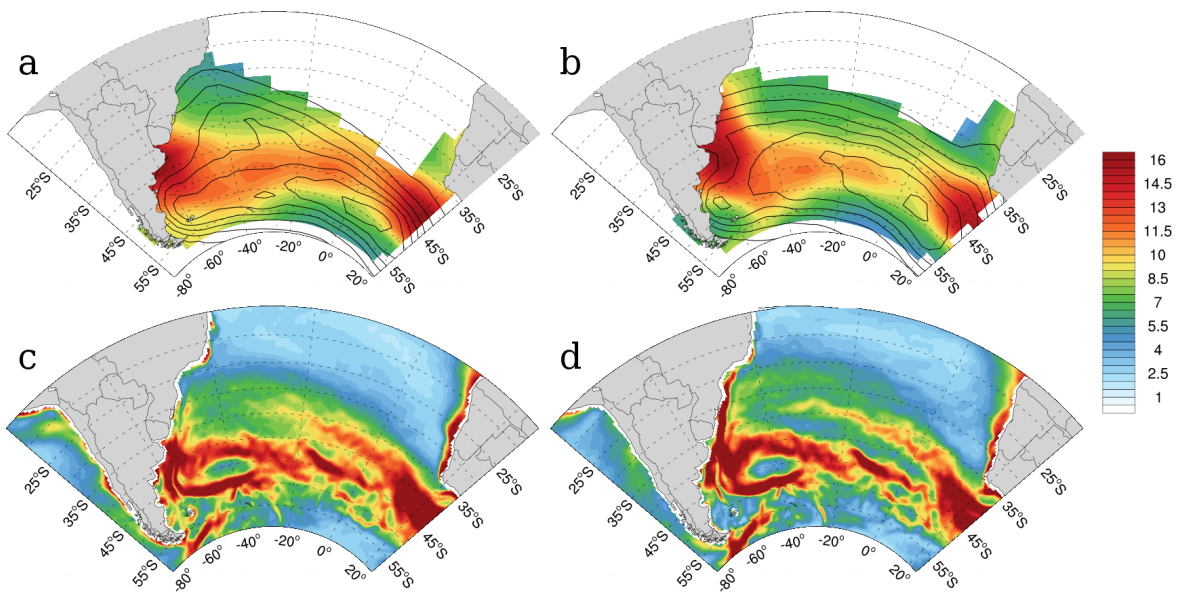

Fig. 7 Spatial distribution of sea surface temperature (SST) gradient at the time of genesis (shaded) and track density (contours each 2 cyclones $\left(10^{6} \mathrm{~km}^{2}\right)^{-1}$ month $^{-1}$ ) in the (a) summer and (b) winter. SST gradient climatology in South Atlantic Ocean in the (c) austral summer and (d) winter. The gradient unit is $10^{-3} \mathrm{~K} \mathrm{~km}^{-1}$. The fields are not plotted where genesis density $<0.2$ cyclones $\left(10^{6} \mathrm{~km}^{2}\right)^{-1}$ month $^{-1}$.

2004; Vera et al, 2006; Drumond et al, 2008). The positive moisture anomaly is more concentrated in the LA PLATA region in the winter, when the SASH southwestward position enhances the moisture transport to this location. Vera et al (2002) and Mendes et al (2007) have shown the importance of moisture transport from the tropics in the development of cyclones in the Southeastern South American coast. During cyclone development the warm and humid fluxes from the SASH feeds the cyclone, providing low-level instability.

The spatial distribution of the potential temperature $(\theta)$ and equivalent potential temperature $\left(\theta_{e}\right)$ lapse rates are considered here as a measure of atmospheric static stability and conditional stability, respectively. In this way, less (more) negative values of $\delta \theta / \delta p$ mean a less (more) stable low-level atmosphere, and positive (negative) values of $\delta \theta_{e} / \delta p$ mean a conditionally unstable (stable) low-level atmosphere. Here we used anomalies from the climatological field, which follow this idea, showing a less stable genesis environment with positive values. Figures $8 \mathrm{c}$ and d show the static stability anomaly in both winter and summer seasons. The static stability difference between the two seasons is bigger over the continent due to changes in the contrast between the lower atmospheric and land surface temperatures. The genesis environment over South American is less statically stable in the winter than in the summer, which may contribute to the greater genesis activity in LA PLATA in the winter. The SE-BR and ARG cyclones develop in a relatively statically unstable environment over the ocean. However, the ARG region presents a less statically stable environment during the summer. In the winter, the SE-BR regions have a more unstable genesis environment. The SE-SAO region shows a less stable environment in both season, but with some variation within its 


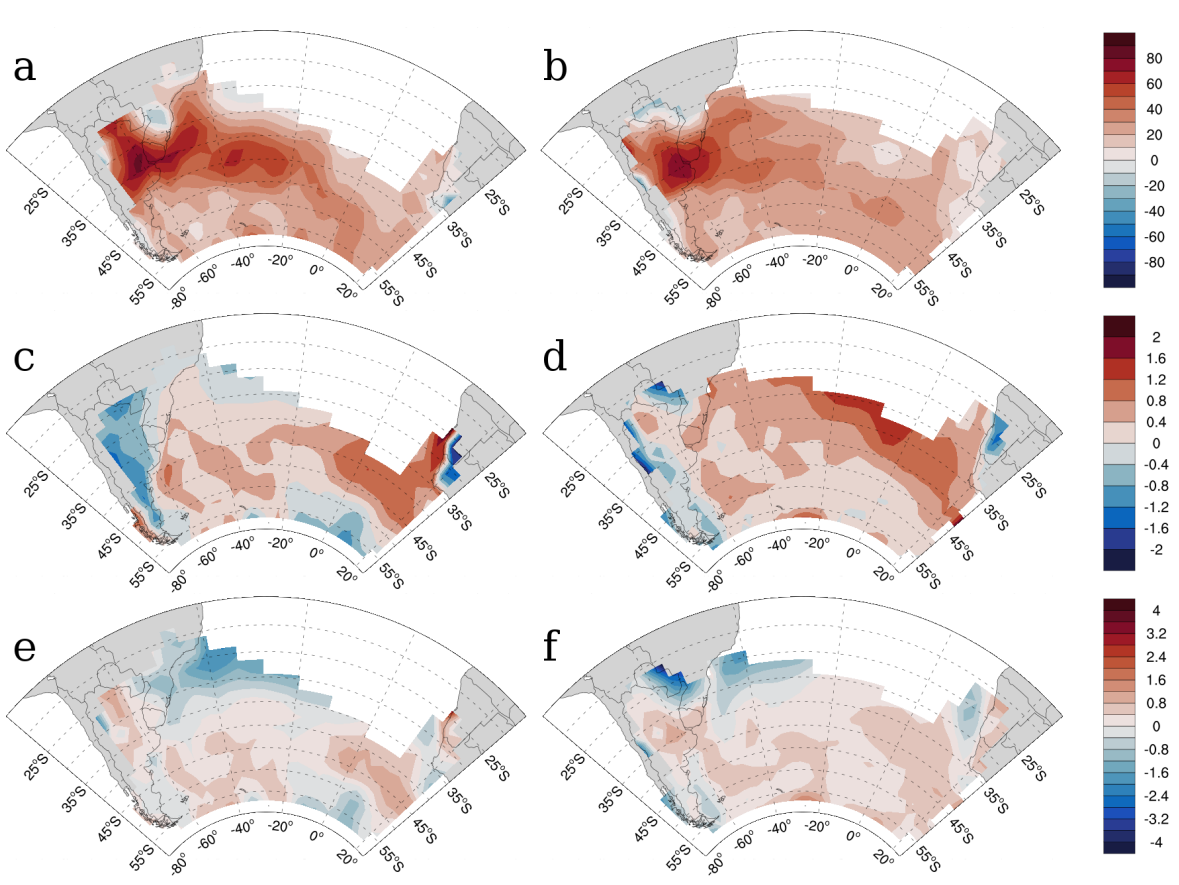

Fig. 8 Spatial distribution of anomalies of the integrated humidity at lower-level $\left(\mathrm{kg} \mathrm{kg}^{-1}\right)$ at the time of genesis in (a) austral summer and (b) winter; $\delta \theta / \delta p\left(10^{-2} \mathrm{KhPa}^{-1}\right)$ at the time of genesis in (c) summer and (d) winter, and; $\delta \theta_{e} / \delta p\left(10^{-2} K_{h P a^{-1}}\right)$ at the time of genesis in (e) summer and (f) winter. The anomalies are computed using the season climatology and the fields are not plotted where genesis density $<0.2$ cyclones $\left(10^{6} \mathrm{~km}^{2}\right)^{-1}$ month $^{-1}$.

domain (less stable in its northern edge). Figures $8 \mathrm{e}$ and $\mathrm{f}$ show the conditional stability anomalies at genesis time. The LA PLATA cyclones develop in a less convectively stable environment when compared to the climatology that may be explained by the positive moisture anomaly at this location. Although the SE-BR region presents a more stable environment (negative anomalies) this region is conditionally unstable in the summer and has a neutral environment in the winter. The reason why these cyclones show a less unstable environment at the time of genesis could be justified by the presence of previous convection, where further evidence of this can be found through the cyclone composite analysis in section 5. Over the ocean, including the SE-SAO region, the genesis environment is less stable than the climatology in both seasons.

Finally, the distributions of the upper-level jet speed anomaly at the time of genesis is shown in Figs.9a and b for summer and winter, respectively. The mean upper-level jet for each season is also presented in Fig.9, where the jet is defined when the speed is greater than $20 \mathrm{~m} \mathrm{~s}^{-1}$. Cyclones tend to develop for upper-level jets which tend to be more intense at the time of genesis than in the mean climatology, as seen through the positive anomaly values over most of the domain in both seasons. The only exception is the cyclones that form 

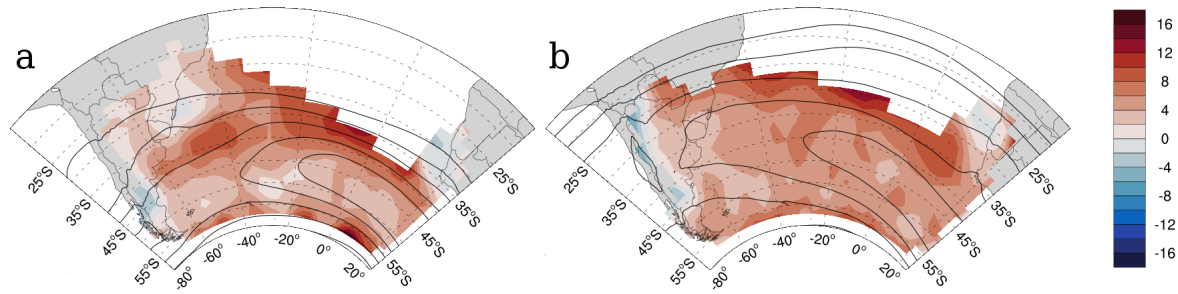

Fig. 9 Spatial distribution of upper-level jet speed anomaly $\left(m s^{-1}\right)$ in austral (a) summer and (b) winter) at the time of genesis. The upper-level jet velocity is computed by the weighted vertical average at each level between 100 and $500 \mathrm{hPa}$. The anomalies are computed using the season climatology, which is contoured each $4 \mathrm{~m} \mathrm{~s}^{-1}$ from $20 \mathrm{~m} \mathrm{~s}^{-1}$. The anomaly

distribution at genesis are not plotted where genesis density $<0.2$ cyclones $\left(10^{6} \mathrm{~km}^{2}\right)^{-1}$ mont $h^{-1}$.

Table 4 Intensity threshold (scaled by $-1 \times 10^{-5} s^{-1}$ ) applied to the selection of $30 \%$ most intense cyclones of each defined genesis region in summer and winter and the number of cyclones used to compute each composite.

\begin{tabular}{ccccc}
\hline \hline & \multicolumn{3}{c}{ DJF } & \multicolumn{2}{c}{ JJA } \\
\hline & threshold & number & threshold & number \\
SE-BR & 7.1 & 61 & 8.8 & 44 \\
LA PLATA & 8.8 & 63 & 10.5 & 92 \\
ARG & 8.2 & 197 & 8.6 & 169 \\
SE-SAO & 8.9 & 167 & 10.0 & 221 \\
\hline \hline
\end{tabular}

over the SE-BR in the summer, that show a genesis environment with a weak upper-level jet (Fig.9a). The weak upper-level jet may suggest that vertical wind shear is not strong in this region and may indicate a subtropical genesis environment (Gozzo et al, 2014).

\section{Cyclone structure}

In this section, the cyclone composites are presented to understand the cyclogenesis precursors of each defined genesis region. An intensity threshold was used to select the strongest $30 \%$ of systems of each region in each season. As discussed in section 3.3, the threshold for each region and season changes according to its maximum intensity. Table 4 shows the limits adopted in each case and the number of systems used in each composite. Figure 10 shows the geographical position of the cyclone center used for the composites at $12 \mathrm{~h}$ before, and at time of genesis for each region in both seasons.

First, an overview of the cyclone structure for each genesis region is examined to explore the general extratropical cyclone features at the time of genesis. The cyclone structure for each region will be shown separately for composites of time steps before and after the time of genesis. For clarity, only composites at $12 \mathrm{~h}$ before the time of genesis and $24 \mathrm{~h}$ after the time of genesis 


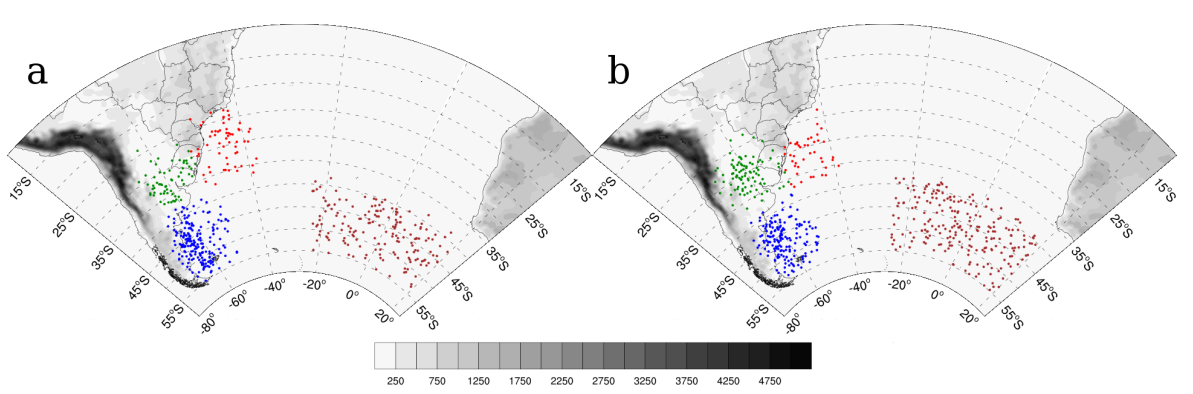

Fig. 10 Map of orography ( $m$; shaded) and geographical positions of the cyclones used in the structure compositing in the (a) summer (DJF) and (b) winter (JJA). The dots denote the position of the cyclone center at the time of genesis, which is also the center position used to the composite at $12 \mathrm{~h}$ before genesis time. The cyclones from each genesis regions are showed in different colors: SE-BR (red), LA PLATA (green), ARG (blue), and SE-SAO (brown).

time will be shown. The discussion of the intensification of the precursors is considered in terms of the thermal advection at $850 \mathrm{hPa}$, geopotential height at $500 \mathrm{hPa}$, vertical velocity, vertically integrated moisture transport and moisture flux convergence $(1000 \mathrm{hPa}-700 \mathrm{hPa})$ and upper-level divergence and geopotential $(200 \mathrm{hPa})$.

\subsection{General structure of cyclone genesis}

The composite structure of $\theta_{e}$ at $925 \mathrm{hPa}$ and MSLP at the time of genesis are shown in Fig.11. The cyclones from all genesis regions tend to form in a temperature gradient zone with the warm isotherms folding towards the center, following the conceptual models of Bjerknes et al (1922) and Shapiro and Keyser (1990). As discussed before (section 2.2), the use of relative vorticity in the cyclone tracking allows the identification of cyclonic features without a closed isobar, as it is possible to see in most of the MSLP composites (Fig.11). The MSLP composite structure also retains the position of the SASH relative to the genesis region. In the SE-BR and LA PLATA regions, the SASH signature in the MSLP mean field is east-northeastward of the cyclone center.

Figure 12 shows the composites of $\mathrm{RH}$ and $\mathrm{PV}$ at $300 \mathrm{hPa}$, and $\theta_{e}$ at 925 $\mathrm{hPa}$ at the time of genesis. The $\mathrm{RH}$ structure in some composites shows a horizontal elongated cloud band across the center. The presence of this cloud band is usually related to a strong thermal gradient at the surface, indicating frontal cloud. In general, this cloud band structure within an extratropical cyclone is called polar front cloud and is associated with a high baroclinic environment (Streten and Troup, 1973; Browning and Roberts, 1994). The presence of a more pronounced cloud band at the time of genesis could be evidence of secondary cyclogenesis (Dacre et al, 2012) and is observed in SE-BR cyclones in the summer and SE-SAO cyclones in both seasons. The composite of $\mathrm{PV}$ at $300 \mathrm{hPa}$ shows an upper-level trough upstream of the cyclone cen- 


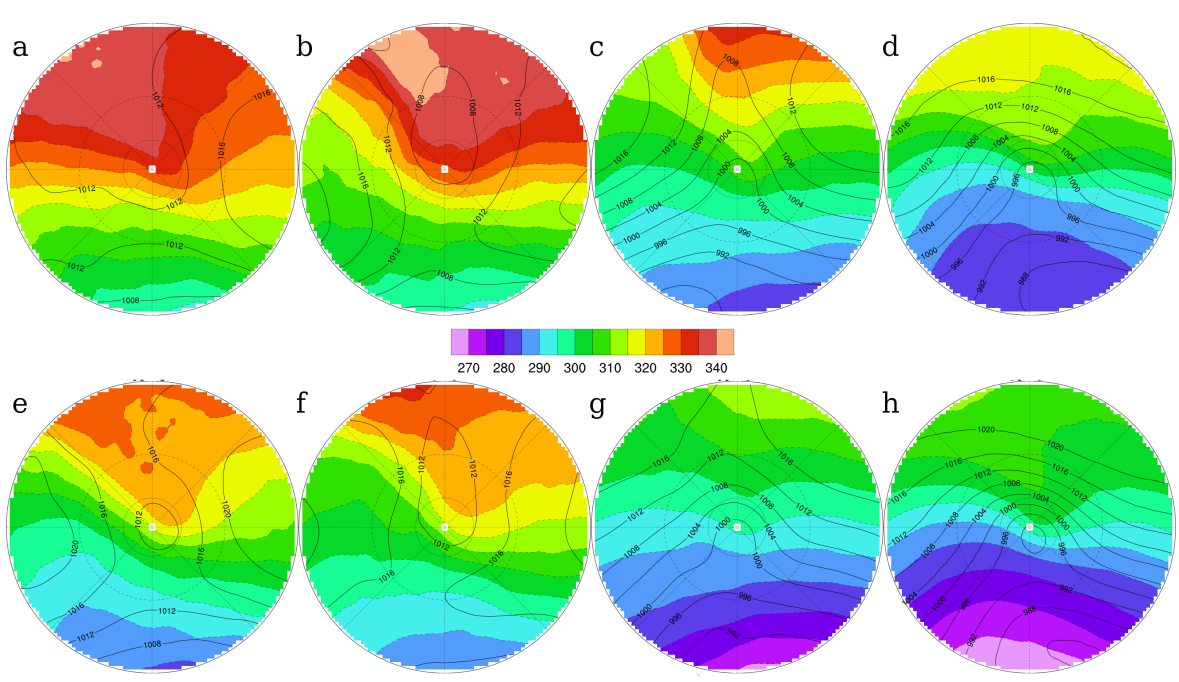

Fig. 11 Composites of equivalent potential temperature $\left(\theta_{e}\right)$ at $925 \mathrm{hPa}(\mathrm{K}$; shaded) and MSLP (hPa; black line) from different genesis regions in the summer (a-d) and winter (f-g): SE-BR (a,e) LA PLATA (b,f), ARG (c,g) and SE-SAO (d,h).

ter in all cyclones. The only exception is the SE-BR cyclones in the summer, where the upper-level trough seems to be weak. The PV values of -2 PVU (1 $\left.\mathrm{PVU}=1 \times 10^{-6} s^{-1}\right)$ indicate a stratospheric intrusion upstream of the cyclone development center, in the Southern Hemisphere. The PV values are higher in cyclogenesis that occurs poleward due to the lower tropopause.

\subsection{Cyclone structure evolution during genesis}

\subsubsection{Southeastern Brazilian Coast (SE-BR)}

Figure 13 shows the composite of the surface temperature advection, winds at $850 \mathrm{hPa}$ and geopotential height at $500 \mathrm{hPa}$ for the SE-BR cyclones. In the summer, the temperature advection is very weak before the time of genesis, increasing slowly after genesis, and showing no evidence of strong frontal characteristics. The winter composites show strong warm advection before genesis and a rapid increase of cold and warm advection after the genesis time. The low-level wind structure and MSLP at the time of genesis (Fig.11a and e) show the southwestern portion of the SASH in the upper-east side of the composites. The SASH is located northwestward of its main position during the winter (e.g., Sun et al, 2017), which may reflect the stronger warm advection before genesis. Moreover, there is strong low-level baroclinicity in the SE-BR region due to the northward shift of the BMC and STSF in the winter. The thermal advection associated with the ocean heat and moisture fluxes can act to decrease the low-level stability contributing to the cyclone development. In 


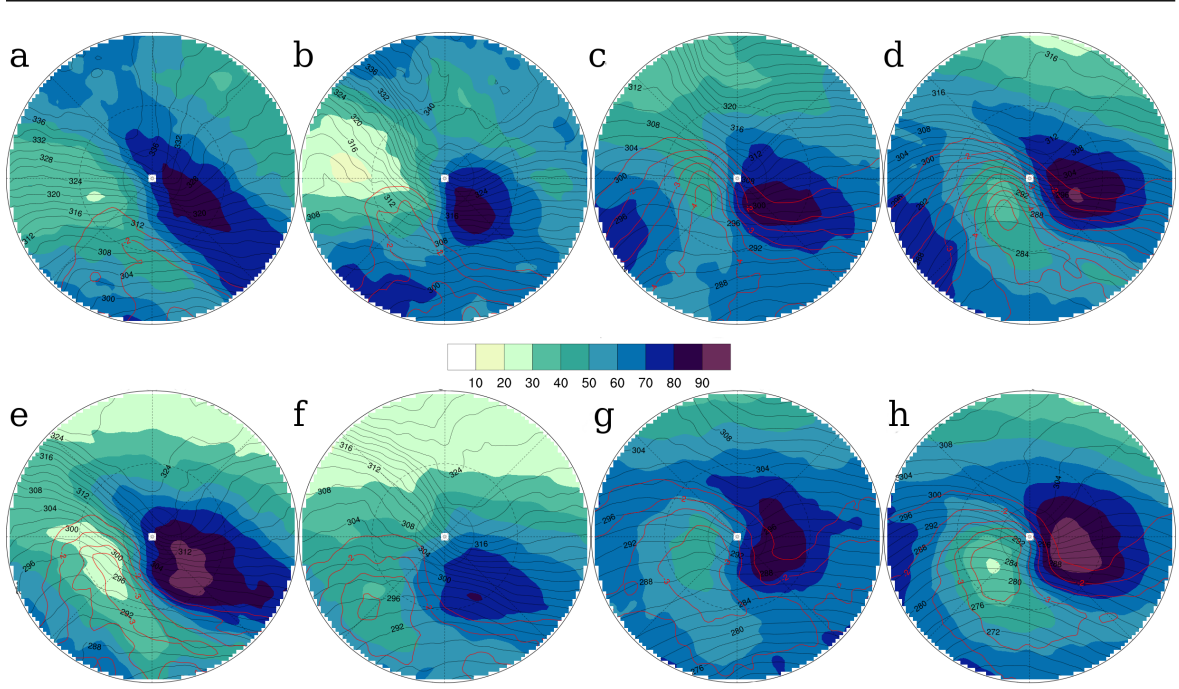

Fig. 12 Composites of equivalent potential temperature $\left(\theta_{e}\right)$ at $925 \mathrm{hPa}$ (K; black lines), $\mathrm{RH}$ (\%; shaded) and $\mathrm{PV}$ at $300 \mathrm{hPa}$ (PVU; red line) from different genesis regions in the summer (a-d) and winter (f-g): SE-BR (a,e) LA PLATA (b,f), ARG (c,g) and SE-SAO (d,h).

both seasons there is a mid-level trough moving to the east that is located westward of the cyclone center at the time of the genesis giving support to the cyclone development. The vertical velocity at $700 \mathrm{hPa}$, the integrated moist flux convergence and transport is shown in Fig.14. In the summer, there is a narrow band of upward motion and moisture convergence with a NW-SE orientation before the time of genesis. This feature in the summer composites may indicate the presence of an "old" front, possibly generated by a "parent" cyclone located southeastward from the genesis area. This can explain the structure analogous of the "polar front cloud" observed for the RH at 300 $\mathrm{hPa}$ at the genesis time for the SE-BR summer composites (Fig.12a). The existence of this convergence strip associated with a cloud band at $300 \mathrm{hPa}$ may be indicative of secondary cyclogenesis. However, the relatively weak thermal advection leads us to believe that this type of secondary development occurs due to the effects of moist deformation strain acting to decrease the frontal temperature gradient of a preexisting front (e.g., Renfrew et al, 1997; Dacre and Gray, 2006). Following the summer cyclone development, the mid-level trough position seems to enhance the vertical movement. However, the proximity of its axis to the cyclone center reveals a small tilt of the system (Fig.13c), which does not totally explain the enhancement of the vertical movement. Figure 15 shows the divergence of the winds and geopotential at $200 \mathrm{hPa}$. The summer composites show the weak upper-level trough that intensifies during the genesis process (Fig.15b). The upper-level divergence is due to a diffluent flow and gives support to the development of the cyclone at low level, enhancing vertical velocity upwards and organizing the small cores of moisture convergence to a 


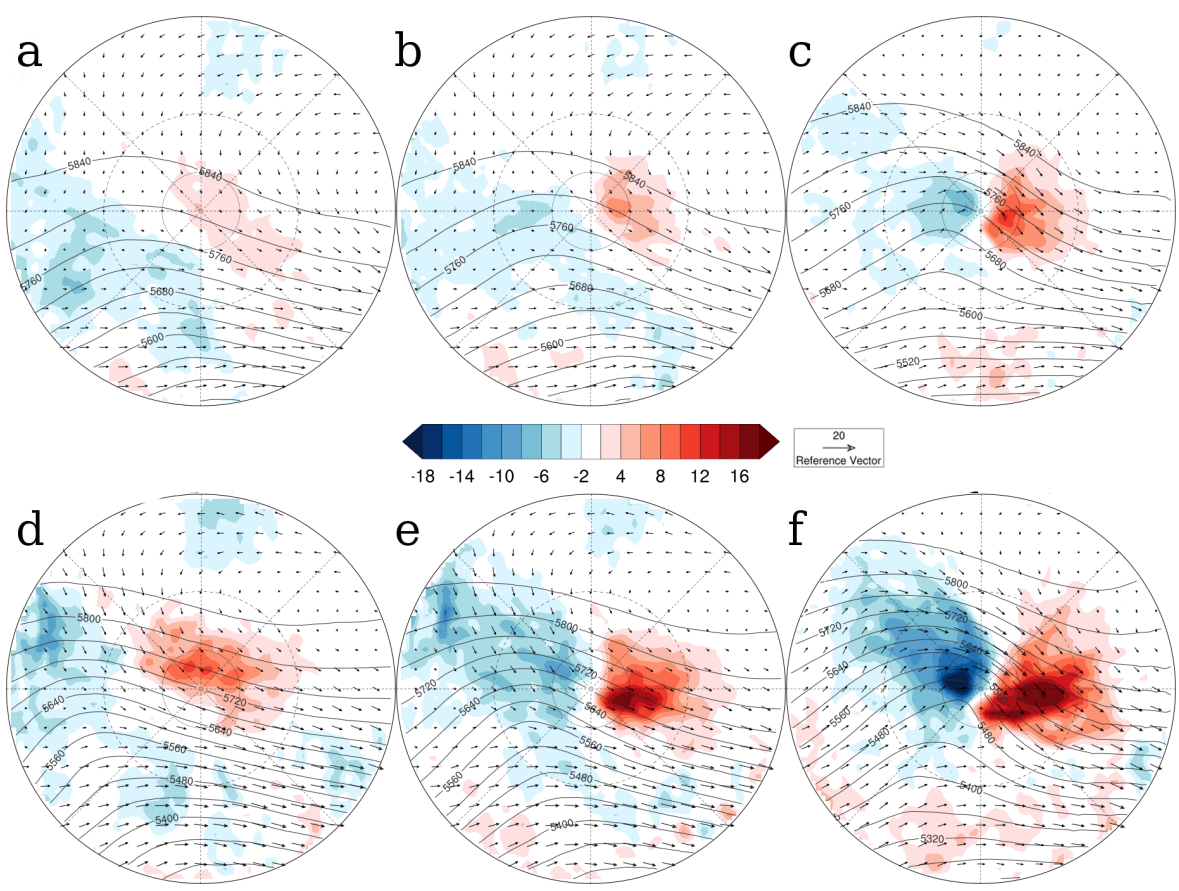

Fig. 13 Composites of SE-BR cyclones temperature advection at $850 \mathrm{hPa}\left(10^{-5} \mathrm{Ks}^{-1}\right.$; shaded), geopotential height at $500 \mathrm{hPa}$ (gpm; blue line) and winds at $850 \mathrm{hPa}\left(\mathrm{ms}^{-1}\right)$ in the $(\mathrm{a}-\mathrm{c})$ summer and $(\mathrm{d}-\mathrm{f})$ winter: $(\mathrm{a}, \mathrm{d})$ at 12 hours before time of genesis; $(\mathrm{b}, \mathrm{e})$ at time of genesis, and; (c,f) at 24 hours after genesis.

larger region at the center of the cyclone at the time of the genesis (Figs.13b and $14 \mathrm{~b})$.

In the winter, the existence of a trailing front is not evident. Despite the presence of upward movement and low-level convergence, they seem to be promoted by the mid-level trough even before genesis (Figs.13d,e). The upperlevel trough at $200 \mathrm{hPa}$ promotes divergence downstream at the same location where there is low-level convergence and mid-level upward motion, showing the coupling of the system even before genesis (Figs.14d,e and 15d,e). When the trough moves towards the low-level warm advection, the genesis occurs, probably due to the consequent reduction of vertical stability. This sequence of events in the SE-BR winter genesis is defined as type B development by Petterssen and Smebye (1971).

It is important to note that, in the summer, the weak upper-level jet (Fig.9a) along with strong moisture convergence at low levels and the diffluent flow at upper levels are typical of subtropical cyclone development (Gozzo et al, 2014; Dutra et al, 2017). Subtropical cyclones in the South Atlantic develop mainly in the SE-BR region (Gozzo et al, 2014), and they may have been included in the composite process since no distinction between subtropical and extratropical cyclones is made. 


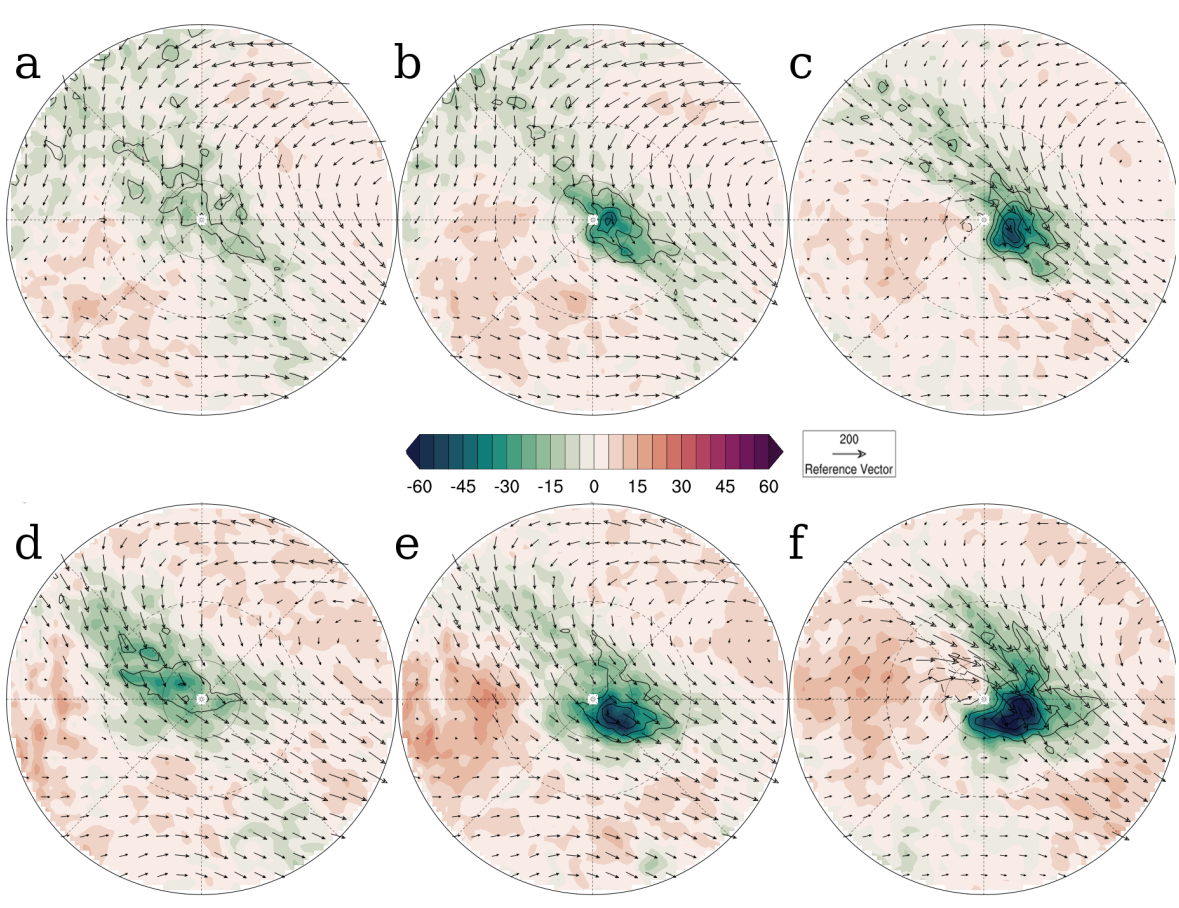

Fig. 14 Composites of SE-BR cyclones omega at $700 \mathrm{hPa}\left(10^{-2} \mathrm{~Pa} \mathrm{~s}^{-1}\right.$; shaded), vertically integrated moisture transport $\left(\mathrm{kg} \mathrm{m}^{-1} \mathrm{~s}^{-1}\right.$; arrows) and moisture flux convergence $\left(10^{-3} \mathrm{~kg}\right.$ $m^{-2} s-1$; contour) at low level $(1000-700 \mathrm{hPa})$ in the (a-c) summer and (d-f) winter: (a,d) at 12 hours before time of genesis; (b,e) at time of genesis, and; (c,f) at 24 hours after genesis. The vertical velocity is contoured every $0.2 \times 10^{-3} \mathrm{~kg} \mathrm{~m}^{-2} \mathrm{~s}-1$, without the zero line and negative values (downward movement) are in dashed line.

\subsubsection{La Plata region (LA PLATA)}

The composites of mean thermal advection and winds at $850 \mathrm{hPa}$ and geopotential height at $500 \mathrm{hPa}$ before and after genesis for cyclones from the LA PLATA region are shown in Figs.16a-c, for the winter. Only the winter composites are shown as this season has more cyclogenesis than summer but the composites produced are similar for both seasons. The differences between the summer and winter composites will be discussed in the text. The signature of the Andes Cordillera, particularly in the composites before genesis time and at genesis is apparent. This signal appears as a thin meridional strip of cold advection. Warm advection exists at the center of cyclone before genesis time in the winter composites, while it starts only at the time of genesis in the summer composites. This warm advection in the winter composite seems to be intensified by the anticyclonic circulation northeast of the cyclone center, which may be the effect of the SASH westward shift in this season. In both seasons the intensification of the warm and cold advection around the cyclone center is faster after genesis time. Although the LA PLATA cyclones start 

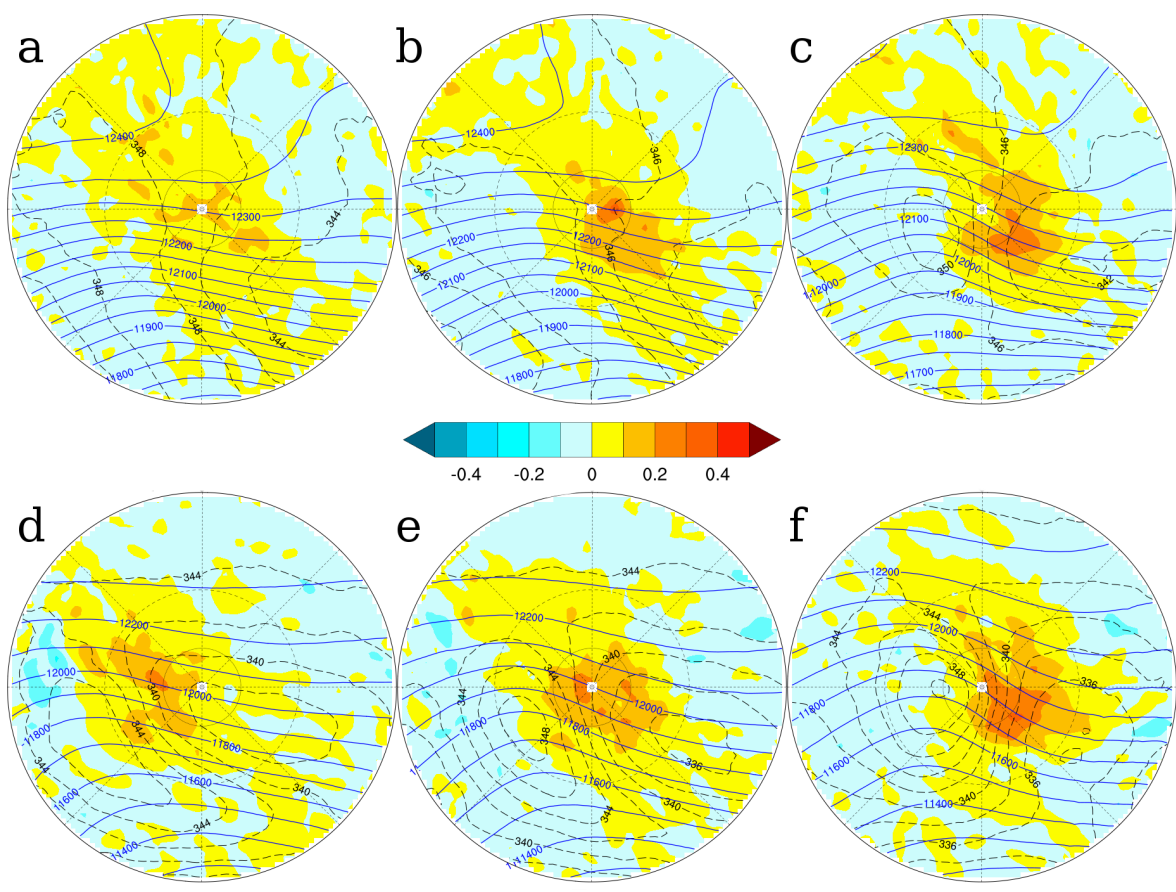

Fig. 15 Composites of SE-BR cyclones potential temperature ( $K$; dashed line), geopotential height (gpm; blue line) and divergence of mass $\left(s^{-1}\right.$; shaded) at $200 \mathrm{hPa}$ in the (a-c) summer and (d-f) winter: (a,d) at 12 hours before time of genesis; (b,e) at time of genesis, and; $(\mathrm{c}, \mathrm{f})$ at 24 hours after genesis.

over the continent, they move eastward over the ocean very quickly due to the narrow shape of South America. In this way, they may be already over the ocean at 12 to 24 hours after the genesis time, where surface fluxes can be intense. In fact, the more intense temperature advection in the winter after genesis can be understood in terms of the northward shift of the BMC. Figures $16 \mathrm{~d}$-f show the vertical velocity at $700 \mathrm{hPa}$, and the integrated moisture flux convergence and transport. In the winter, it is possible to see subsidence in a meridional strip promoted by descending air from the Andes Cordillera.

The elongated shape of the low observed in composites at the genesis time (Figs.11b and f) makes us believe that it is an influence of the thermalorographic lows called Northwestern Argentina Low (NAL, Seluchi et al, 2003) and the Chaco Low (CL, Saulo et al, 2004). The NAL is thermally induced in summer due to surface fluxes above a desert region and orographically induced in winter by forced subsidence during an upper-level trough occurrence and is usually located around $30^{\circ} \mathrm{S}$ close to the Andes lee slope. The CL is basically thermally induced and is located further to the north around $20^{\circ} \mathrm{S}$ above Paraguay and Bolivia (Seluchi and Saulo, 2012). The southward low level circulation combined by CL and NAL allows a well-organized low-level northerly current. The presence of the SASH westward of its main position linked with 
the CL and NAL southward circulation in the winter may be responsible for the intensified warm advection before genesis. In the summer, the CL intensifies the transport of humidity to the LA PLATA region (Saulo et al, 2004), that may help the genesis. The tracking algorithm used here identifies the earlier stages of the cyclones that intensify further eastward, near the Southeastern South American coast and where using MSLP would first identify them. This fact reinforces the argument for the influence of thermal-orographic lows in the cyclogenesis in the LA PLATA region in both seasons, enhancing the moisture transport and warm advection. Ribeiro et al (2016) show that development of warm fronts in this region are related to the eastern edge of the CL and NAL northwesterly flow and, most of the time, are followed by cyclogenesis. Also, Seluchi et al (2003) and Seluchi and Saulo (1998) highlight the role of NAL formation in the reduction of static stability before genesis time due to warm and moist advection. The upper-level pattern of the LA PLATA cyclone composites (Figs.16g-i) is similar to the SE-BR cyclones. In the summer, the presence of a diffluent flow promotes divergence that enhances and organizes the low-level convergence at the genesis time (not shown), similar to the SEBR composites. In the winter LA PLATA composites, there is an upper-level trough moving eastward reinforcing the low-level system.

\subsubsection{Argentina region $(A R G)$}

Although composites for the ARG cyclones were produced for summer and winter, only summer composites are presented here. Very few aspects are different between the summer and winter composites and are discussed in the text. Figures 17a-c show the composite of the mean temperature advection and winds at $850 \mathrm{hPa}$ and geopotential height at $500 \mathrm{hPa}$ of the ARG cyclones before, at and after genesis times for winter. In the ARG composites, as in the LA PLATA ones, the presence of the Andes Cordillera is observed through a meridional band of cold advection westward of the composite center. The mountain chain height at this latitude $\left(45^{\circ} \mathrm{S}\right)$ is lower than at $30^{\circ} \mathrm{S}$, and the lee effects are not so strong as in the LA PLATA region. However, it is possible to see a moving trough at $500 \mathrm{hPa}$ that intensifies from $-12 \mathrm{~h}$ to genesis time due to low-level cold air advection and/or its interaction with the Andes stationary trough (e.g., Gan and Rao, 1994). In the ARG cyclone composites, the cold advection is stronger at the time of genesis, particularly in the summer. This strong cold advection occurs above the land surface, that is warmer than the upper air temperature in the summer, decreasing the static stability at the low level. In the winter, the reduction of static stability is lower as the cold advection in less intense. When compared with the SE-BR and LA PLATA cyclones, the ARG cyclone temperature advection intensifies rapidly in the $12 \mathrm{~h}$ interval after genesis time (not shown). Figures $17 \mathrm{~d}-\mathrm{f}$ present the vertical velocity at $700 \mathrm{hPa}$, and the integrated moisture flux convergence and transport and Figs.17g-i show the upper level geopotential $(200 \mathrm{hPa})$ and the divergence of winds at $200 \mathrm{hPa}$. It is possible to see the $500 \mathrm{hPa}$ geopotential trough westward of the composite cyclone center inducing upward vertical mo- 

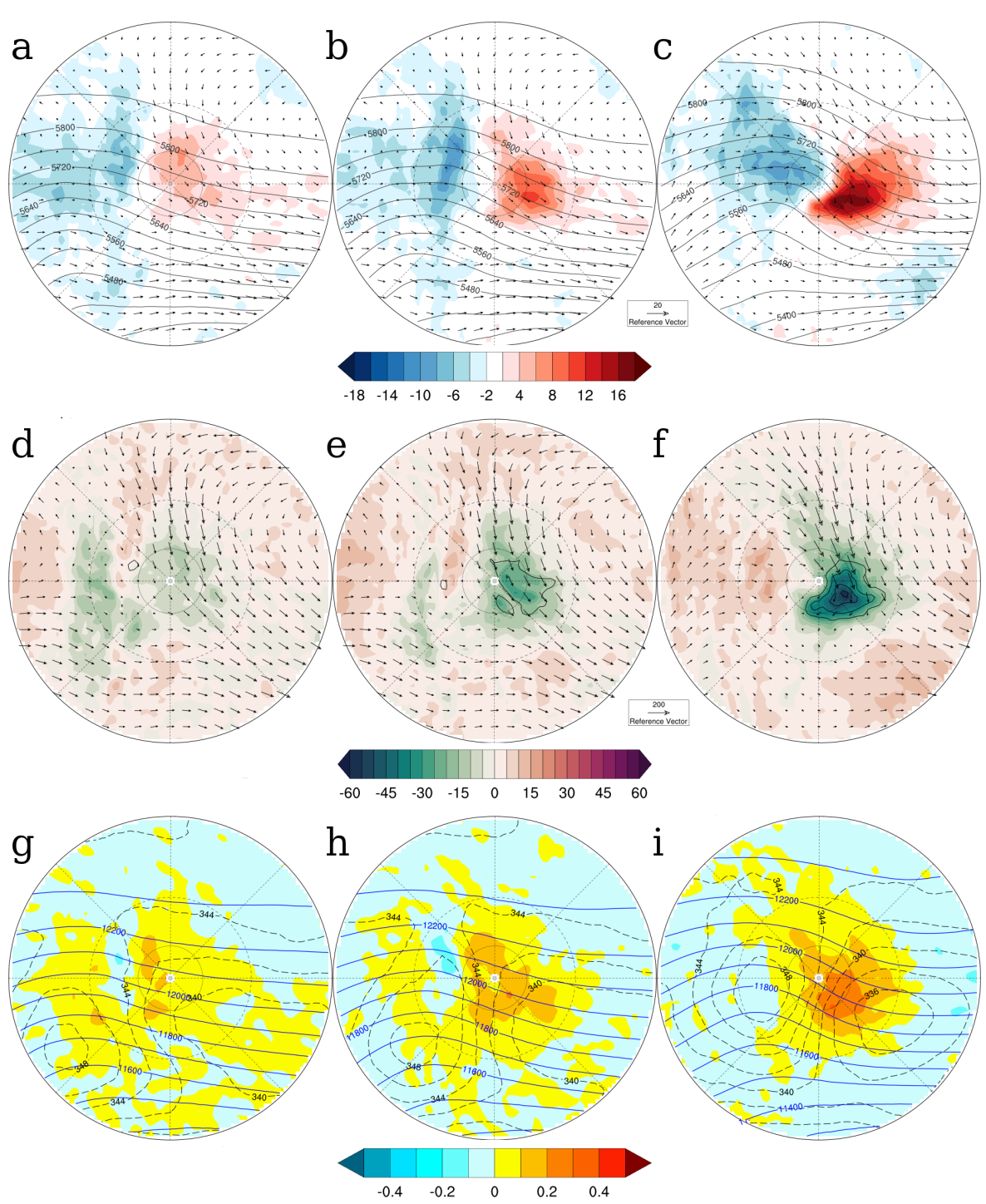

Fig. 16 Composites of LA PLATA cyclones in the winter: (a-c) temperature advection at $850 \mathrm{hPa}\left(10^{-5} \mathrm{~K} \mathrm{~s}^{-1}\right.$; shaded), geopotential height at $500 \mathrm{hPa}$ (gpm; blue line) and winds at $850 \mathrm{hPa}\left(\mathrm{ms}^{-1}\right)$; (d-f) omega at $700 \mathrm{hPa}\left(10^{-2} \mathrm{~Pa} \mathrm{~s}^{-1}\right.$; shaded), vertically integrated moisture transport $\left(\mathrm{kg} \mathrm{m}^{-1} \mathrm{~s}^{-1}\right.$; arrows $)$ and moisture flux convergence $\left(10^{-3} \mathrm{~kg} \mathrm{~m} \mathrm{~m}^{-2} \mathrm{~s}-1\right.$; contour) at low level $(1000-700 \mathrm{hPa})$, and; (g-i) potential temperature ( $K$; dashed line), geopotential height (gpm; blue line) and divergence of mass $\left(s^{-1}\right.$; shaded) at $200 \mathrm{hPa}$. Composites $(\mathrm{a}, \mathrm{d}, \mathrm{g})$ at 12 hours before the time of genesis; (b,e,h) at the time of genesis, and; (c,f,i) at 24 hours after the time of genesis. The vertical velocity is contoured every $0.2 \times 10^{-3} \mathrm{~kg} \mathrm{~m}^{-2} \mathrm{~s}-1$, without the zero line and negative values (downward movement) are in dashed line. 

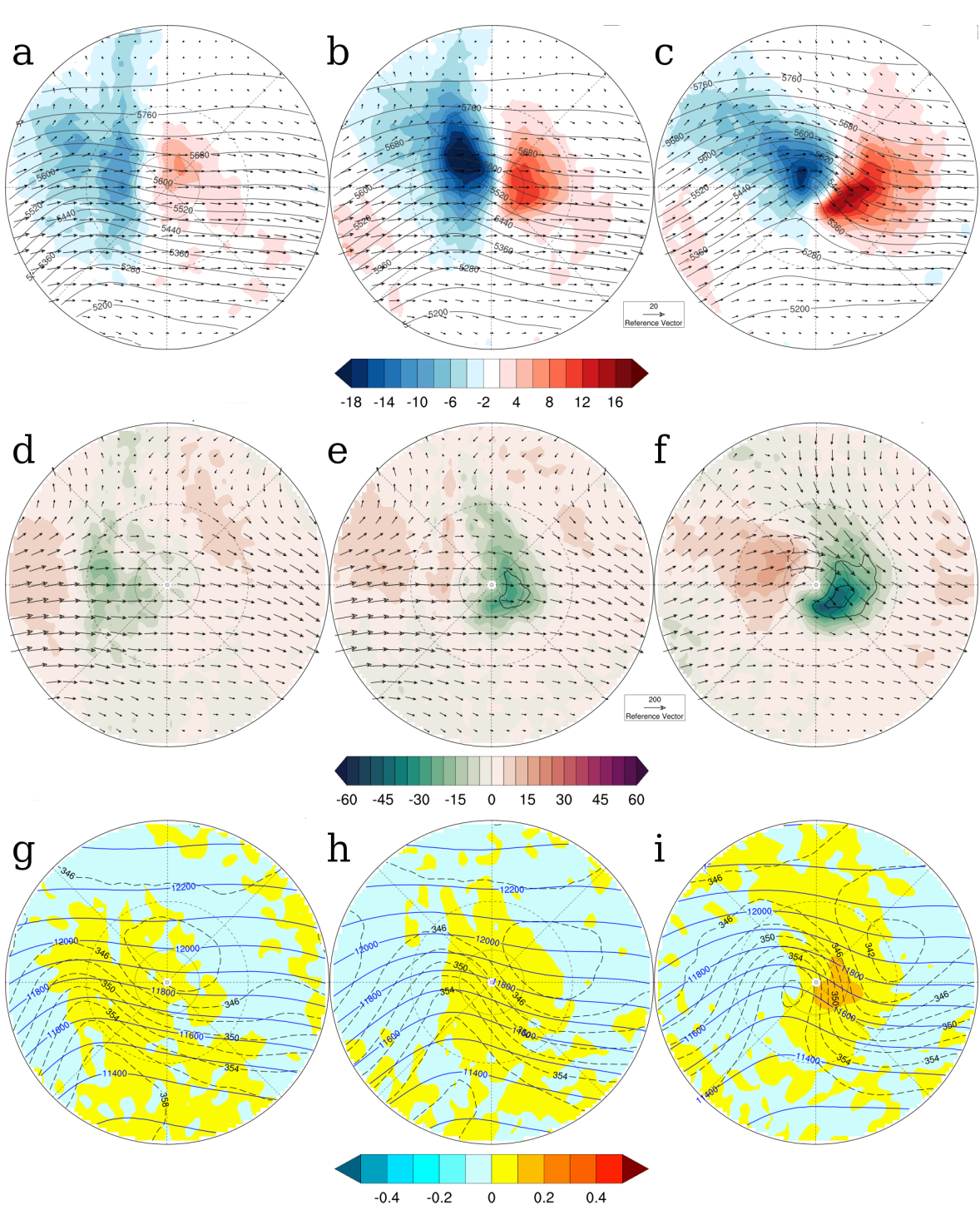

Fig. 17 As in Fig.16 but for the composites of ARG cyclones in the summer.

tion. This baroclinic system is reinforced by an upper-level trough (Fig.17h). There is no strong influence of horizontal moisture transport and low-level convergence in the ARG region genesis process.

\subsubsection{Southeastern South Atlantic Ocean (SE-SAO)}

Only cyclone composites from winter are shown here for the SE-SAO region, for clarity. Again, differences between summer and winter composites will be 
highlighted in the text. The winter composites of the mean temperature advection and winds at $850 \mathrm{hPa}$ and geopotential height at $500 \mathrm{hPa}$ before and after genesis for SE-SAO cyclones are presented in Figs.18a-c. This shows there is a strong warm advection 12 hours before genesis in the center of the composite together with a cold advection westward. This cold advection at lower levels seems to be associated with the mid-level trough at $12 \mathrm{~h}$ before genesis. The cold and warm advection increases rapidly after genesis time, being slightly stronger in the winter. The vertical velocity, vertically integrated moisture transport and moisture flux convergence are shown in Figs.18d-f. There is a convergence of moisture near the cyclone center $12 \mathrm{~h}$ before the genesis time associated with a strong upward movement at $700 \mathrm{hPa}$. At the time of genesis, the $500 \mathrm{hPa}$ trough moves eastward into the low-level warm advection region and reinforces the upward motion of moist and warm air. The SE-SAO cyclones seem to develop northwestward of another cyclone as it is possible to see through the curvature of the geopotential field at $500 \mathrm{hPa}$ (Fig.18b) and MSLP structure at the time of genesis (Figs.11d and h). This secondary development occurs on the cold side of the parent cyclone. Some authors have related secondary development in the cold sector associated with the intrusion of dry stratospheric air (e.g., Browning et al, 1997; Iwabe and da Rocha, 2009). In fact, at the time of genesis, SE-SAO cyclones present a dry slot associated with intense cyclonic $\mathrm{PV}$ at $300 \mathrm{hPa}$ in the cold sector close to their center (Figs.12d and h). The evidence of secondary cyclogenesis is in agreement with the high initial vorticity of the SE-SAO cyclones (Fig. 4 and Table 3). The major part of case studies (not shown) showed SE-SAO cyclones developing within the cold front and cold sector of a parental cyclone located southeastward. There were also minority cases of downward development, with the parental cyclone placed west/northwestward.

\section{Summary and Final Remarks}

The paper has produced a new climatology for the entire South Atlantic domain, including the open ocean, to provide new insights into the conditions leading to genesis in different regions of the South Atlantic. Two scientific questions were addressed (i) What are the main forcing mechanisms that control cyclone development in each genesis region of the South Atlantic in their most active season?; and, (ii) Are there any differences in the genesis precursors and structure of intense cyclones that originate in distinct genesis regions? The climatologies obtained by this study are in general in agreement with previous studies that found a main South Atlantic storm track between $40^{\circ} \mathrm{S}$ and $55^{\circ} \mathrm{S}$ and a subtropical path coming from Uruguay $\left(35^{\circ} \mathrm{S}\right)$ and the Southern Brazilian coast $\left(30^{\circ} \mathrm{S}\right)$. The genesis density statistic indicates three main cyclogenesis regions on the South American coast: the Southern Brazilian coast (SE-BR, $30^{\circ} \mathrm{S}$ ), above the continent near the La Plata river discharge region (LA PLATA, $35^{\circ} \mathrm{S}$ ) and the southeastern coast of Argentina (ARG, $\left.40^{\circ} \mathrm{S}-55^{\circ} \mathrm{S}\right)$. A fourth genesis region was found centered at $45^{\circ} \mathrm{S}$ and $10^{\circ} \mathrm{W}$ 

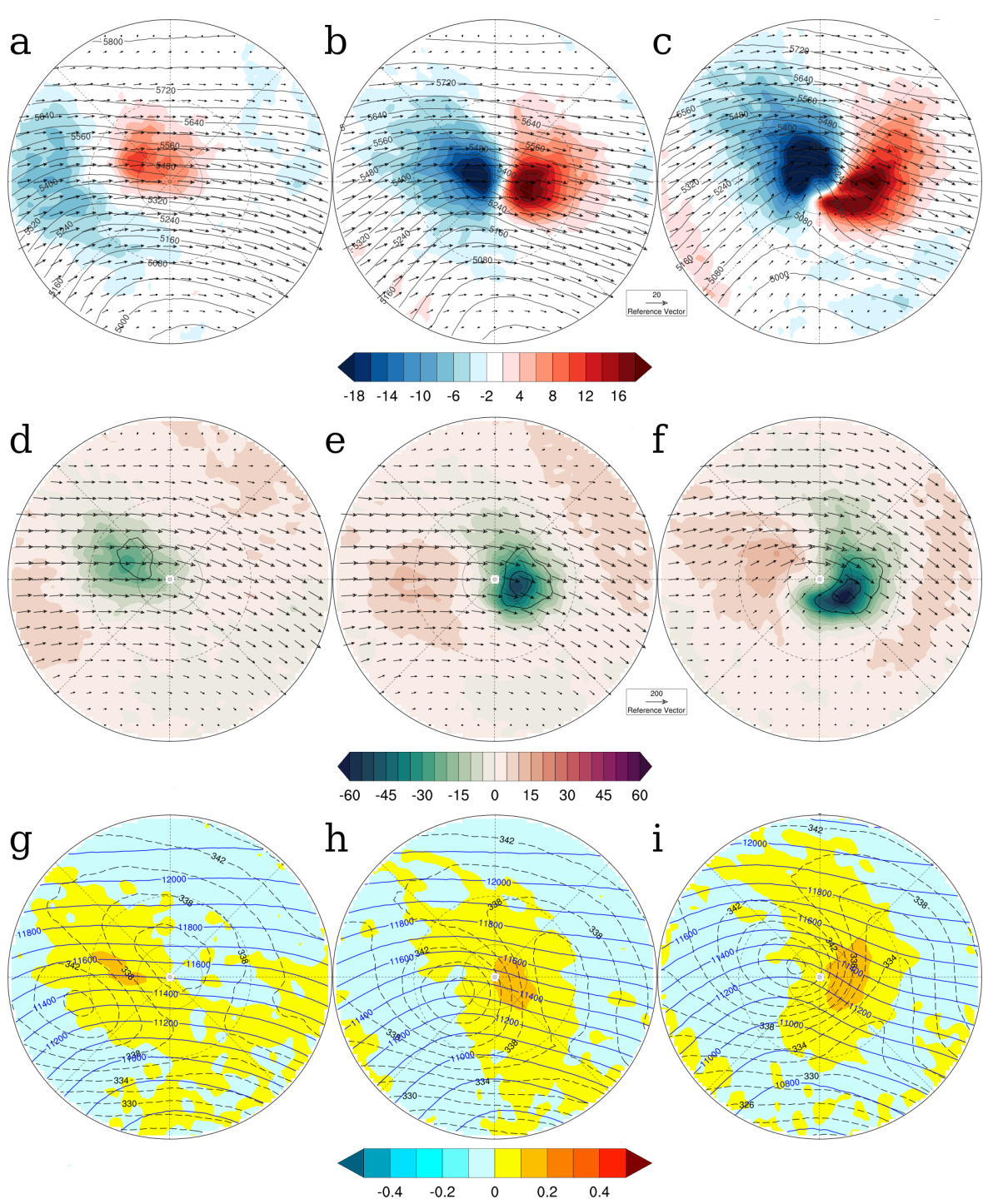

Fig. 18 As in Fig.16 but for the composites of SE-SAO cyclones in the winter.

in the Southeastern South Atlantic (SE-SAO). The adjustment of the tracking constraints done to avoid tracking issues over South America improved the identification of genesis, particularly in the ARG and SE-BR. The genesis density maps show that the SE-BR and ARG regions are more active in the summer (DJF) while the LA PLATA and SE-SAO regions are more active in the winter, as reported by Hoskins and Hodges (2005) and Reboita et al (2010a). However, the seasonal variability is not evident for the SE-BR and ARG regions according to the numbers of cyclones per region. 
We produced spatial distribution maps of the cyclone characteristics, including information from their genesis environment to answer the first scientific question. We found differences in the genesis environment of the South Atlantic domain. Northward of $35^{\circ} \mathrm{S}$, two distinct processes lead to genesis in the summer and winter. In the summer, low-level forcing is more critical in the genesis process, primarily associated with moisture transport. In the winter, a stronger upper-level jet may play an important role in genesis through baroclinic instability. Moreover, the northward shift of the SST gradient near the Southeastern South American coast may be an essential feature of genesis and intensification at $35^{\circ} \mathrm{S}$. Southward of $35^{\circ} \mathrm{S}$, cyclones develop in a high baroclinic environment with a smaller influence of low-level humidity when compared to the other regions.

The second science question concerns the differences in the genesis precursors of cyclones generated in different genesis regions of the domain. To answer this we performed radial composites of mean fields before, at the time of genesis and after. We found similarities and differences between the genesis precursors for each region. The intense cyclones of all regions are influenced by a midlevel trough giving dynamical support to the genesis. Although, cyclones from the SE-BR and LA PLATA present a stronger low-level forcing when compared to the ARG and SE-SAO cyclones. Cyclone composites reinforce the importance of moisture fluxes to genesis in the SE-BR region, including evidence of secondary development on trailing fronts during the summer. The LA PLATA cyclone development is supported by the warm advection promoted by the thermal-orographic lows (CL and NAL) on the lee side of the Andes. The ARG cyclone genesis is mainly associated with traditional baroclinic development, reinforced by the interaction of mid-level troughs with the Andes and the low static stability in the summer. The SE-SAO cyclones develop in a high baroclinic region in the cold sector of a parent cyclone.

There are extensive efforts to study and understand climate change, and this work contributes to the formulation of the questions and hypothesis to what we can expect about changes in cyclone behavior in the South Atlantic. Several studies have shown a decrease in cyclone activity over the globe justified by the reduction of low-level baroclinicity (e.g., Geng and Sugi, 2003). However, the effect of the moistening in a warmer climate to cyclones is still not clear (e.g., Schneider et al, 2010). Thus, our findings indicate that different South Atlantic genesis regions may respond differently to climate change where they have distinct forcing mechanisms. This will be investigated further in future work using climate models, e.g., CMIP5/CMIP6 models, and dynamical downscaling.

Acknowledgements The authors acknowledge financial support provided by the Conselho Nacional de Desenvolvimento Científico e Tecnológico - Brasil (CNPq) - Grant 141658/20150 - and the Coordenação de Aperfeiçoamento de Pessoal de Nível Superior - Brasil (CAPES) - Finance Code 001. The CFSR data was developed by NOAA's National Centers for Environmental Prediction (NCEP). The data for this study are from NOAA's National Operational Model Archive and Distribution System (NOMADS), which is maintained at NOAA's National Centers for Environmental Information (NCEI). 


\section{References}

Bengtsson L, Hodges KI, Easch M, Keenlyside N, Kornblueh L, Luo JJ, Yamagata $\mathrm{T}$ (2007) How may tropical cyclones change in a warmer climate? Tellus 59A:539-561, DOI 10.1111/j.1600-0870.2007.00251.x

Bengtsson L, Hodges KI, Keenlyside N (2009) Will extratropical storms intensify in a warmer climate? J Climate 22(9):2276-2301, DOI 10.1175/2008JCLI2678.1

Berbery EH, Vera CS (1996) Characteristics of the Southern Hemisphere winter storm track with filtered and unfiltered data. J Atmos Sci 53(3):468-481

Bjerknes J, , Solberg H (1922) Life cycle of cyclones and the polar front theory of atmospheric circulation. Geofys Publ 3:1-18

Bluestein H (1992) Synoptic-Dynamic Meteorology in Midlatitudes: Principles of Kinematics and Dynamics, Vol. 1. Oxford University Press

Bolton D (1980) The computation of equivalent potential temperature. Mon Wea Rev 108:1046-1053

Browning KA, Roberts NM (1994) Structure of a frontal cyclone. Quart J Roy Meteor Soc 120(520):1535-1557, DOI 10.1002/qj.49712052006

Browning KA, Roberts NM, Illingworth AJ (1997) Mesoscale analysis of the activation of a cold front during cyclogenesis. Quart J Roy Meteor Soc 123(544):2349-2374, DOI 10.1002/qj.49712354410

Campos EJD, Lentini CAD, Miller JL, Piola AR (1999) Interannual variability of the sea surface temperature in the South Brazil Bight. Geophys Res Lett 26(14):2061-2064, DOI 10.1029/1999GL900297

Catto JL, Shaffrey LC, Hodges KI (2010) Can climate models capture the structure of extratropical cyclones? J Climate 23(7):1621-1635, DOI 10.1175/2009JCLI3318.1

da Rocha RP, Sugahara S, da Silveira RB (2004) Sea waves generated by extratropical cyclones in the South Atlantic Ocean: Hindcast and validation against altimeter data. Wea Forecasting 19(2):398-410, DOI 10.1175/15200434(2004)019;0398:SWGBEC ¿2.0.CO;2

Dacre HF, Gray SL (2006) Life-cycle simulations of shallow frontal waves and the impact of deformation strain. Quart J Roy Meteor Soc 132(620):21712190, DOI 10.1256/qj.05.238

Dacre HF, Gray SL (2009) The Spatial Distribution and Evolution Characteristics of North Atlantic Cyclones. Mon Wea Rev 137:99-115

Dacre HF, Hawcroft MK, Stringer MA, Hodges KI (2012) An Extratropical Cyclone Atlas: A tool for illustrating cyclone structure and evolution characteristics. Bull Amer Meteor Soc 93(10):1497-1502, DOI 10.1175/BAMSD-11-00164.1

Dias Pinto JR, Da Rocha RP (2011) The energy cycle and structural evolution of cyclones over southeastern South America in three case studies. J Geophys Res: Atmos 116(14):1-17, DOI 10.1029/2011JD016217

Dias Pinto JR, Reboita MS, Da Rocha RP (2013) Synoptic and dynamical analysis of subtropical cyclone Anita (2010) and its potential for tropical transition over the South Atlantic Ocean. J Geophys Res: Atmos 
118(19):10,870-10,883, DOI 10.1002/jgrd.50830

Drumond A, Nieto R, Gimeno L, Ambrizzi T (2008) A Lagrangian identification of major sources of moisture over Central Brazil and La Plata Basin. J Geophys Res: Atmos 113(D14), DOI 10.1029/2007JD009547

Dutra LMM, da Rocha RP, Lee RW, Peres JRR, de Camargo R (2017) Structure and evolution of subtropical cyclone Anita as evaluated by heat and vorticity budgets. Quart J Roy Meteor Soc 143(704):1539-1553, DOI $10.1002 /$ qj. 3024

Ek MB, Mitchell KE, Lin Y, Rogers E, Grunmann P, Koren V, Gayno G, Tarpley JD (2003) Implementation of noah land surface model advances in the national centers for environmental prediction operational mesoscale eta model. J Geophys Res: Atmos 108(D22):n/a-n/a, DOI 10.1029/2002JD003296, 8851

Funatsu BM, Gan MA, Caetano E (2004) A case study of orographic cyclogenesis over South America. Atmosfera 17(2):91-113

Gan MA, Rao VB (1991) Surface Cyclogenesis over South America. Mon Wea Rev 119:1293-1302

Gan MA, Rao VB (1994) The influence of the Andes Cordillera on transient disturbances. Mon Wea Rev 122:1141-1157, DOI 10.1175/15200493(1994)122¡1141:TIOTAC ¿2.0.CO;2

Geng Q, Sugi M (2003) Possible change of extratropical cyclone activity due to enhanced greenhouse gases and sulfate aerosols - Study with a high-resolution AGCM. J Climate 16(13):2262-2274, DOI 10.1175/15200442(2003)16;2262:PCOECA ¿2.0.CO;2

Gordon AL (1989) Brazil-Malvinas Confluence - 1984. Deep Sea Research Part A Oceanographic Research Papers 36(3):359 - 384, DOI https://doi.org/10.1016/0198-0149(89)90042-3

Gozzo LF, da Rocha RP (2013) Air-sea interaction processes influencing the development of a Shapiro-Keyser type cyclone over the Subtropical South Atlantic Ocean. Pure and Applied Geophysics 170(5):917-934, DOI 10.1007/s00024-012-0584-3

Gozzo LF, da Rocha RP, Reboita MS, Sugahara S (2014) Subtropical cyclones over the southwestern South Atlantic: Climatological aspects and case study. J Climate 27(22):8543-8562, DOI 10.1175/JCLI-D-14-00149.1

Griffies S, Harrison MJ, Pacanowski RC, Rosati A (2004) A technical guide to MOM4. GFDL Ocean Group Tech. Rep. 5, NOAA/Geophysical Fluid Dynamics Laboratory, version prepared on August 23, 2004

Grise KM, Son SW, Gyakum JR (2013) Intraseasonal and interannual variability in North American storm tracks and its relationship to Equatorial Pacific variability. Mon Wea Rev 141(10):3610-3625, DOI 10.1175/MWRD-12-00322.1

Hodges KI (1994) A general-method for tracking analysis and its application to meteorological data. Mon Wea Rev 122(11):2573-2586, DOI 10.1175/15200493(1994)122ز2573:AGMFTA¿2.0.CO;2

Hodges KI (1995) Feature tracking on the unit sphere. Mon Wea Rev 123(12):3458-3465, DOI 10.1175/1520- 
0493(1995)123¡3458:FTOTUS ¿2.0.CO;2

Hodges KI (1996) Spherical nonparametric estimators applied to the UGAMP model integration for AMIP. Mon Wea Rev 124(12):2914-2932, DOI 10.1175/1520-0493(1996)124;2914:SNEATT ¿2.0.CO;2

Hodges KI (1999) Adaptative Constraints for Feature Tracking. Mon Wea Rev 127:1362-1373, DOI 10.1175/1520-0493(1999)127;1362:ACFFT ¿2.0.CO;2

Hodges KI, Lee RW, Bengtsson L (2011) A Comparison of Extratropical Cyclones in Recent Reanalyses ERA-Interim, NASA MERRA, NCEP CFSR, and JRA-25. J Climate 24:4888-4906, DOI 10.1175/2011JCLI4097.1

Hoskins A, Hodges KI (2005) A New Perspective on the Southern Hemisphere Storm Tracks. J Climate 18:4108-4129

Hoskins BJ, Hodges KI (2002) New Perspectives on the Northern Hemisphere Winter Storm Tracks. J Atmos Sci 59:1041-1061, DOI 10.1175/15200469(2002)059;1041:NPOTNH $; 2.0 . \mathrm{CO} ; 2$

Inatsu M, Hoskins BJ (2004) The zonal asymmetry of the Southern Hemisphere winter storm track. J Climate 17(24):4882-4892, DOI 10.1175/JCLI3232.1

Innocentini V, Neto EDSC (1996) A case study of the 9 august 1988 South Atlantic storm: Numerical simulations of the wave activity. Wea Forecasting 11(1):78-88, DOI 10.1175/1520-0434(1996)011;0078:ACSOTA ¿2.0.CO;2

Iwabe CMN, da Rocha RP (2009) An event of stratospheric air intrusion and its associated secondary surface cyclogenesis over the south atlantic ocean. J Geophys Res: Atmospheres 114(D9), DOI 10.1029/2008JD011119, d09101

Iwabe CMN, Reboita MS, de Camargo R (2011) Estudo de caso de uma situação atmosférica entre 12 e 19 de setembro de 2008 com algumas características semelhantes ao evento catarina. Rev Bras Meteorol 26(March 2011):67-84

Jones DA, Simmonds I (1993) A climatology of Southern Hemisphere extratropical cyclones. Climate Dyn 9(3):131145, DOI 10.1007/BF00209750

Kanamitsu M, Ebisuzaki W, Woollen J, Yang SK, Hnilo JJ, Fiorino M, Potter GL (2002) NCEPDOE AMIP-II Reanalysis (R-2). Bull Amer Meteor Soc 83(11):1631-1644, DOI 10.1175/BAMS-83-11-1631

Krüger LF, da Rocha RP, Reboita MS, Ambrizzi T (2012) RegCM3 nested in HadAM3 scenarios A2 and B2: Projected changes in extratropical cyclogenesis, temperature and precipitation over the South Atlantic Ocean. Climatic Change 113(3-4):599-621, DOI 10.1007/s10584-011-0374-4

Marengo JA, Soares WR, Saulo C, Nicolini M (2004) Climatology of the lowlevel jet east of the Andes as derived from the NCEP-NCAR Reanalyses: Characteristics and temporal variability. J Climate 17(12):2261-2280, DOI 10.1175/1520-0442(2004)017;2261:COTLJE:2.0.CO;2

Mendes D, Souza EP, Trigo F Isabel, Miranda PMA (2007) On precursors of South American cyclogenesis. Tellus 59A:114-121, DOI 10.1111/j.16000870.2006.00215.x

Mendes D, Souza EP, Marengo J, Mendes MCD (2010) Climatology of extratropical cyclones over the South American-southern oceans sector. Theoretical and Applied Climatology 100(3):239-250, DOI 10.1007/s00704-009- 
0161-6

Murray FW (1967) On the computation of saturation vapor pressure. J Appl Meteor 6(1):203-204, DOI 10.1175/15200450(1967)006;0203:OTCOSV ¿2.0.CO;2

Murray RJ, Simmonds I (1991) A numerical scheme for tracking cyclone centres from digital data Part II: application to January and July general circulation model simulations. Australian Meteorological Magazine 39:167-180

Olson DB, Podest GP, Evans RH, Brown OB (1988) Temporal variations in the separation of Brazil and Malvinas currents. Deep Sea Research Part A Oceanographic Research Papers 35(12):1971 - 1990, DOI https://doi.org/10.1016/0198-0149(88)90120-3

Orlanski I, Katzfey J (1991) The life cycle of a cyclone wave in the Southern Hemisphere. Part I: Eddy energy budget. J Atmos Sci 48(17):1972-1998, DOI 10.1175/1520-0469(1991)048;1972:TLCOAC ¿2.0.CO;2

Parise CK, Calliari LJ, Krusche N (2009) Extreme storm surges in the south of Brazil: atmospheric conditions and shore erosion. Braz J Oceanogr 57:175 - 188, DOI 10.1590/S1679-87592009000300002

Petterssen S, Smebye SJ (1971) On the development of extratropical cyclones. Quart J Roy Meteor Soc 97(414):457-482, DOI 10.1002/qj.49709741407

Piola AR, Campos EJD, Möller OO, Charo M, Martinez C (2000) Subtropical shelf front off eastern south america. J Geophys Res: Oceans 105(C3):65656578, DOI 10.1029/1999JC000300

Piva ED, Moscati MCdL, Gan MA (2008) Papel dos fluxos de calor latente e sensível em superfície associado a um caso de ciclogênese na costa leste da América do Sul. Rev Bras Meteorol 23(4):450-476

Piva ED, Gan MA, Rao VB (2010) Energetics of winter troughs entering South America. Mon Wea Rev 138(4):1084-1103, DOI 10.1175/2009MWR2970.1

Piva ED, Gan MA, Moscati MCdL (2011) The role of latent and sensible heat fluxes in an explosive cyclogenesis over the South American East Coast. J Meteor Soc Japan 89(6):637-663, DOI 10.2151/jmsj.2011-604

Reboita MS, Ambrizzi T, da Rocha RP (2009) Relationship between the southern annular mode and southern hemisphere atmospheric systems. Rev Bras Meteorol 24:48-55, DOI 10.1590/S0102-77862009000100005

Reboita MS, da Rocha RP, Ambrizzi T, Sugahara S (2010a) South Atlantic Ocean cyclogenesis climatology simulated by regional climate model (RegCM3). Climate Dyn 35(7-8):1331-1347, DOI 10.1007/s00382-009-06687

Reboita MS, Gan MA, da Rocha RP, Ambrizzi T (2010b) Precipitation regimes in South America: a bibliography review. Rev Bras Meteorol 25:185 - 204, DOI 10.1590/S0102-77862010000200004

Reboita MS, da Rocha RP, de Souza MR, Llopart M (2018) Extratropical cyclones over the southwestern South Atlantic Ocean: HadGEM2-ES and RegCM4 projections. Int J Climatol 0(0):1-14, DOI 10.1002/joc.5468

Renfrew IA, Thorpe AJ, Bishop CH (1997) The role of the environmental flow in the development of secondary frontal cyclones. Quart J Roy Meteor Soc 123(542):1653-1675, DOI 10.1002/qj.49712354210 
Ribeiro BZ, Seluchi ME, Chou SC (2016) Synoptic climatology of warm fronts in Southeastern South America. International Journal of Climatology 36(2):644-655, DOI 10.1002/joc.4373

Saha S, Moorthi S, Pan HL, Wu X, Wang J, Nadiga S, Tripp P, Kistler R, Woollen J, Behringer D, Liu H, Stokes D, Grumbine R, Gayno G, Wang J, Hou YT, Chuang H, Juang HMH, Sela J, Iredell M, Treadon R, Kleist D, Delst PV, Keyser D, Derber J, Ek M, Meng J, Wei H, Yang R, Lord S, Dool H, Kumar A, Wang W, Long C, Chelliah M, Xue Y, Huang B, Schemm JK, Ebisuzaki W, Lin R, Xie P, Chen M, Zhou S, Higgins W, Zou CZ, Liu Q, Chen Y, Han Y, Cucurull L, Reynolds RW, Rutledge G, Goldberg M (2010) The ncep climate forecast system reanalysis. Bull Amer Meteor Soc 91(8):1015-1058, DOI 10.1175/2010BAMS3001.1

Sanders F, Gyakum JR (1980) Synoptic-dynamic climatology of the bomb. Mon Wea Rev (10):1589-1606, DOI 10.1175/15200493(1980)108;1589:SDCOT ¿2.0.CO;2

Satyamurty P, Ferreira CC, Gan MA (1990) Cyclonic vortices over South America. Tellus A 42(1):194-201

Saulo AC, Seluchi ME, Nicolini M (2004) A case study of a Chaco Low-Level Jet event. Mon Wea Rev 132(11):2669-2683, DOI 10.1175/MWR2815.1

Schneider T, Gorman PAO, Levine XJ (2010) Water vapor and the dynamics of climate changes. Reviews of Geophysics 48(RG3001):1-22, DOI 10.1029/2009RG000302, URL http://dx.doi.org/10.1029/2009RG000302;

Seluchi ME, Saulo AC (1998) Possible mechanisms yielding an explosive coastal cyclogenesis over South America: experiments using a limited area model. Aust Meteor Mag 47:309-320

Seluchi ME, Saulo AC (2012) Baixa do Noroeste Argentino e Baixa do Chaco: caracterísitcas, diferenças e semelhanças. Rev Bras Meteorol 27(1):49-60

Seluchi ME, Saulo AC, Nicolini M, Satyamurty P (2003) The northwestern argentinean low: A study of two typical events. Mon Wea Rev 131(10):23612378, DOI 10.1175/1520-0493(2003)131;2361:TNALAS ¿2.0.CO;2

Shapiro MA, Keyser D (1990) Fronts, jet streams and the tropopause. In: Newton CW, Holopainen EO (eds) Extratropical Cyclones, The Erik Palmen Memorial Volume, Amer. Meteor. Soc., pp 167-191

Simmonds I, Keay K (2000) Mean southern hemisphere extratropical cyclone behavior in the 40-year NCEP-NCAR reanalysis. J Climate 13(5):873-885, DOI 10.1175/1520-0442(2000)013;0873:MSHECB i2.0.CO;2

Sinclair MR (1994) An objective cyclone climatology for the Southern Hemisphere. Mon Wea Rev 122(10):2239-2256, DOI 10.1175/15200493(1994)122¡2239:AOCCFT¿2.0.CO;2

Sinclair MR (1995) A climatology of cyclogenesis for the Southern Hemisphere. Mon Wea Rev 123:1601-1619

Sinclair MR (1997) Objective identification of cyclones and their circulation intensity, and climatology. Wea Forecasting 12(3):595-612, DOI 10.1175/15200434(1997)012;0595:OIOCAT ¿2.0.CO;2

Stopa JE, Cheung KF (2014) Intercomparison of wind and wave data from the ECMWF Reanalysis Interim and the NCEP Climate Forecast System 
Reanalysis. Ocean Modelling 75:65-83, DOI 10.1016/j.ocemod.2013.12.006 Streten NA, Troup AJ (1973) A synoptic climatology of satellite observed cloud vortices over the southern hemisphere. Quart J Roy Meteor Soc 99(419):56-72, DOI 10.1002/qj.49709941906

Sun X, Cook KH, Vizy EK (2017) The South Atlantic Subtropical High: Climatology and interannual variability. J Climate 30(9):3279-3296, DOI 10.1175/JCLI-D-16-0705.1, URL https://doi.org/10.1175/JCLI-D-160705.1

Taljaard JJ (1967) Development, distribution and movement of cyclones and anticyclones in the Southern Hemisphere during the IGY. J Appl Meteor 6(6):973-987, DOI 10.1175/1520-0450(1967)006;0973:DDAMOC ¿2.0.CO;2

Trenberth KE (1991) Storm Tracks in the Southern Hemisphere. J Atmos Sci 48(19):2159-2178

Vera C, Higgins W, Amador J, Ambrizzi T, Garreaud R, Gochis D, Gutzler D, Lettenmaier D, Marengo J, Mechoso CR, Nogues-Paegle J, Dias PLS, Zhang C (2006) Toward a unified view of the American Monsoon Systems. J Climate 19(20):4977-5000, DOI 10.1175/JCLI3896.1

Vera CS, Vigliarolo PK, Berbery EH (2002) Cold season synoptic-scale waves over subtropical South America. Mon Wea Rev 130(3):684-699, DOI 10.1175/1520-0493(2002)130;0684:CSSSWO ¿2.0.CO;2 